\title{
Trial Application of the Facility Safeguardability Assessment Process to the NuScale SMR Design
}
GA Coles
J Hockert
ET Gitau
MD Zentner

January 2013

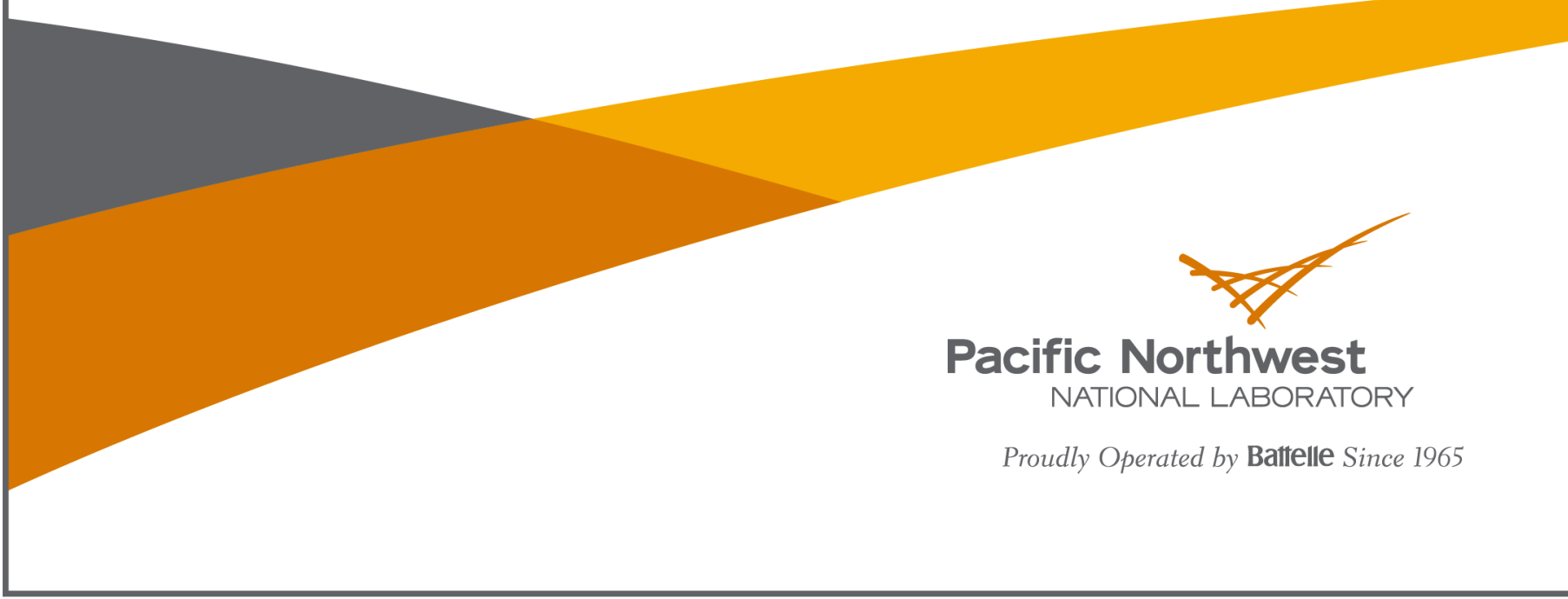




\title{
DISCLAIMER
}

This report was prepared as an account of work sponsored by an agency of the United States Government. Neither the United States Government nor any agency thereof, nor Battelle Memorial Institute, nor any of their employees, makes any warranty, express or implied, or assumes any legal liability or responsibility for the accuracy, completeness, or usefulness of any information, apparatus, product, or process disclosed, or represents that its use would not infringe privately owned rights. Reference herein to any specific commercial product, process, or service by trade name, trademark, manufacturer, or otherwise does not necessarily constitute or imply its endorsement, recommendation, or favoring by the United States Government or any agency thereof, or Battelle Memorial Institute. The views and opinions of authors expressed herein do not necessarily state or reflect those of the United States Government or any agency thereof.

\author{
PACIFIC NORTHWEST NATIONAL LABORATORY \\ operated by \\ BATTELLE \\ for the \\ UNITED STATES DEPARTMENT OF ENERGY \\ under Contract DE-AC05-76RL01830
}

Printed in the United States of America
Available to DOE and DOE contractors from the Office of Scientific and Technical Information,
P.O. Box 62, Oak Ridge, TN 37831-0062;
ph: (865) 576-8401
fax: $(865) 576-5728$
email: reports@adonis.osti.gov
Available to the public from the National Technical Information Service 5301 Shawnee Rd., Alexandria, VA 22312 ph: (800) 553-NTIS (6847)
email: orders@ntis.gov <http://www.ntis.gov/about/form.aspx>
Online ordering: http://www.ntis.gov

This document was printed on recycled paper. 


\title{
Trial Application of the Facility Safeguardability Assessment Process to the NuScale SMR Design
}

\author{
GA Coles \\ ET Gitau \\ J Hockert \\ MD Zentner
}

January 2013

Prepared for

the U.S. Department of Energy

under Contract DE-AC05-76RL01830

Pacific Northwest National Laboratory

Richland, Washington 99352 



\section{Executive Summary}

The International Atomic Energy Agency (IAEA) is tasked with verifying that commitments made by States as part of their safeguards agreements with the IAEA are fulfilled. The IAEA verifies declarations made by States and detects undeclared activities in States through the implementation of a Safeguards Approach (SA) for the facility and a State Level Approach (SLA) for the entire state. At the facility level, the SA consists of measures to verify the special fissionable material present and its movement as declared by the facility. The SA measures also provide assurance that the facility operations are as declared and that the facility is not being misused. All these safeguards measures at the facility level contribute to the SLA for the entire state.

"Safeguards by Design" (SBD) is the practice of incorporating features to support application of these measures into facility designs throughout the entire facility lifecycle. The ultimate goal of SBD is to increase the safeguardability of a facility, a qualitative measure of "the degree of ease with which a nuclear energy system can be effectively and efficiently placed under international safeguards" (GIF 2006). Over the last 20 years, a growing volume of SBD literature has focused on safeguards principles and best practices. However, these informational and analytical tools have been independently developed with little effort made to form a consistent, structured methodology for a facility designer and the facility's safeguards experts to use in assessing the safeguardability of their design.

To address this need, the National Nuclear Security Administration's (NNSA) Next Generation Safeguards Initiative funded the Pacific Northwest National Laboratory (PNNL), Brookhaven National Laboratory, and several consultants to develop the Facility Safeguardability Assessment (FSA) process (Bari et al. 2012). FSA is a screening process used by a facility designer to focus their attention on the aspects of their facility or process design that would most benefit from application of SBD principles and practices. The process is meant to identify the most relevant guidance within the SBD tools for enhancing the safeguardability of the design. In fiscal year (FY) 2012, NNSA sponsored PNNL to evaluate the practical applicability of FSA by applying it to the NuScale small modular nuclear power plant design. This report documents the application of the FSA process, presenting conclusions regarding its efficiency and robustness rather than evaluating the safeguardability of the NuScale design. The report describes the NuScale safeguards design concept and presents considerations for functional "infrastructure" guidelines to ensure safeguardability.

The application of FSA to the NuScale design consisted of four activities:

1. The authors compared the NuScale design to the design of a current large pressurized water reactor using the FSA screening tool (Bari et al. 2012). The comparison proved useful in identifying those aspects of the design that posed safeguards challenges.

2. The authors reviewed IAEA safeguards guidance for future water cooled reactors to identify applicable design concepts to resolve the safeguards challenges (IAEA 1998). The product of this review was a NuScale Safeguard Design Concept (SDC).

3. The authors validated the SDC with a limited pathway analysis. This trial application and interaction with NuScale project staff demonstrated the value of a fourth activity that had not been considered during the previous FSA process development. 
4. The authors considered a set of "infrastructure" functional guidelines that more effectively accommodate a wide range of safeguards approaches. These functional guidelines should be sufficient to ensure safeguardability and are analogous to the use of voluntary standards or regulatory guidance to ensure adequate safety in design. These guidelines shifted the intent of the project from identifying specific candidate safeguards measures for the SDC to identifying the infrastructure capable of supporting a range of possible safeguards measures.

The successful application of the FSA process to the NuScale design generated a number of findings and lessons learned. One major finding states that the "infrastructure" functional guidelines appear to provide more flexibility in accommodating evolving safeguards technologies over the lifetime of the facility. Second, the trial application of FSA demonstrated that the level of effort required to use this process to improve the safeguardability of new SMR designs is likely to be acceptable to small modular reactor designers. The trial application, including the extension of the approach to develop functional guidelines and the documentation of the process, was performed in under a month. In addition to identifying these two findings, the authors identified seven lessons learned:

- Designers would benefit from accessible training materials on key safeguards terms and concepts to facilitate the completion of the FSA screening tool.

- Infrastructure functional guidelines would augment the FSA process, leading to design approaches likely to provide more flexibility in accommodating evolving safeguards technologies.

- There is sufficient information available during the conceptual/preliminary design phase for effective application of the FSA process.

- Despite the shift in focus to infrastructure functional guidelines, the development of the safeguards design concept remains a vital part of the FSA process.

- There is limited utility in having the designer conduct a path analysis of the safeguards design concept, particularly with the IAEA engaged early in the design process.

- Development of functional guidelines for designers requires additional interpretation of safeguards guidance.

- Coordination with designers requires a structured approach early in the FSA process.

A valuable next step in FY 2013 is to have NuScale designers conduct a detailed review of the FSA process to provide additional insights about the practical utility of the FSA approach and the flexibility and robustness of the process. 


\section{Acronyms and Abbreviations}

$\mathrm{AC}$

ALARA

$\mathrm{C} / \mathrm{S}$

CCTV

$\mathrm{CoK}$

CVC

CVD

DC

DHRS

ECCS

FSA

FY

IAEA

IIT

IIV

KMPs

LEU

LOCA

LWR

MBA

MIVS

MWe

MWt

NDA

NNRI

NNSA

NSS

PIV

PWR

SA

SAS

SBD

SDC

SFM

SLA

SMR alternating current

as low as reasonably achievable

containment/surveillance

closed-circuit television

continuity of knowledge

chemical and volume control

Cerenkov Viewing Device

direct current

decay heat removal system

emergency core cooling system

Facility Safeguardability Assessment

fiscal year

International Atomic Energy Agency

interim inventory taking

interim inventory verification

key measurement points

low enrichment uranium

loss of coolant accident

light water reactor

material balance area

modular integrated video system

megawatts electric

megawatts thermal

non-destructive assay

no-notice random inspection

National Nuclear Security Administration

NuScale Nuclear Steam Supply

physical inventory verification

pressurized water reactor

Safeguards Approach

shutdown accumulator system

safeguards by design

(NuScale) safeguard design concept

Special Fissionable Material

State Level Approach

small modular reactor 
SNRI

short-notice random inspection

TID

tamper-indicating device 


\section{Contents}

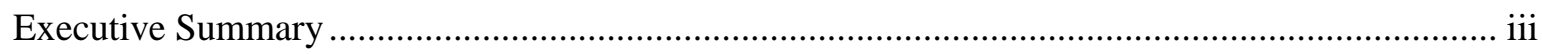

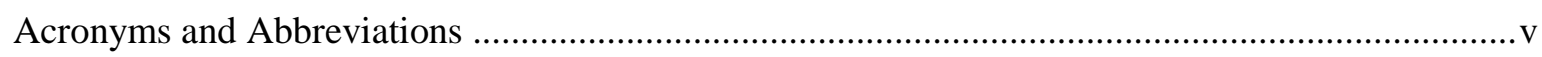

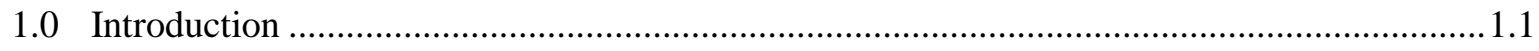

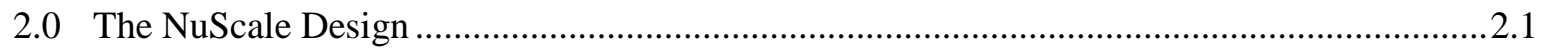

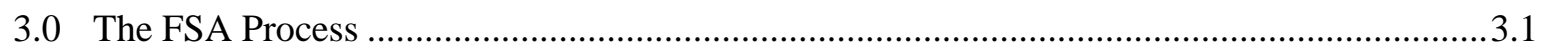

3.1 Application of the FSA Process to the NuScale Design................................................. 3.1

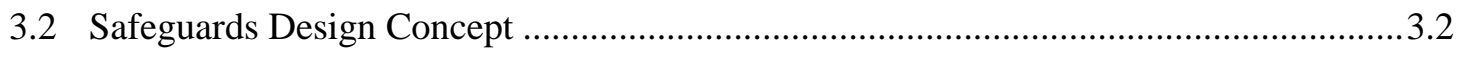

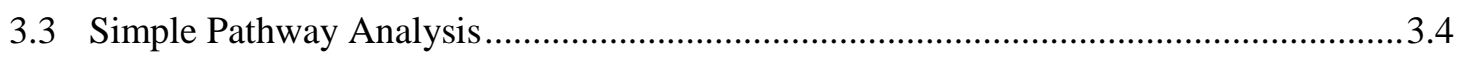

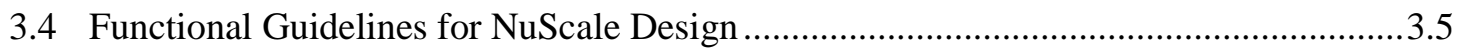

4.0 Lessons Learned for FSA .......................................................................................... 4.1

4.1 Safeguards Training Materials Would Facilitate Completion of the FSA Screening

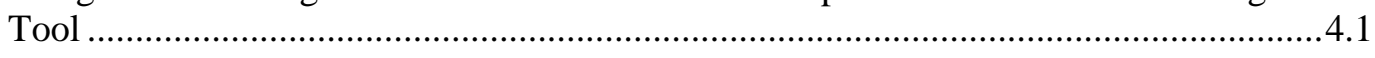

4.2 Infrastructure Functional Guidelines Augment the FSA Process, Leading to Designs with Greater Flexibility to Accommodate Evolving Safeguards Technologies ...............4.1

4.3 FSA is Applicable During the Conceptual/Preliminary Design Phase ..........................4.2

4.4 Despite the Shift to Infrastructure Functional Guidelines, the Development of the Safeguards Design Concept Remains a Vital Part of the FSA Process...........................4.2

4.5 There is Limited Utility in Having the Designer Conduct a Path Analysis of the Safeguards Design Concept .................................................................................. 4.2

4.6 Additional Guidance for Designers is Needed to Help Interpret Safeguards

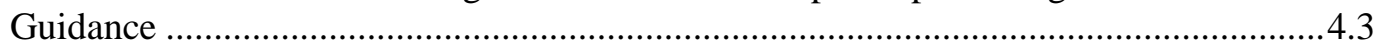

4.7 Coordination with Designers Requires a Structured Approach ................................... 4.3

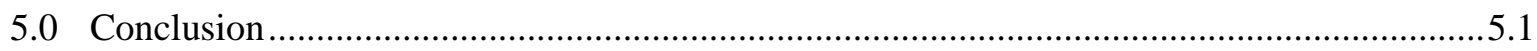

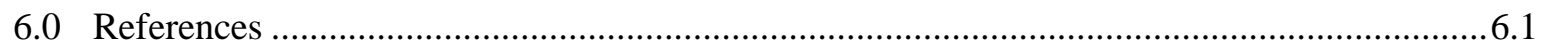

Appendix A Expanded NuScale Design Information for FSA Review ….................................... A.1

Appendix B Reference Pressurized Water Reactor Description ................................................... B. 1

Appendix C Completed Facility Safeguardability Assessment Screening Tool............................ C.1

Appendix D Considerations in Deriving Functional Guidelines for the Application of

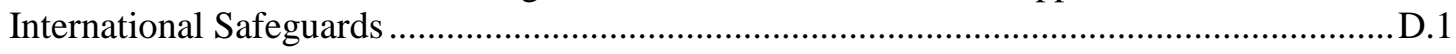




\section{Figures}

Figure 2.1. Nuclear Steam Supply Module Cutaway Showing Core and Internals ......................2.1

Figure 2.2. NuScale Reactor Building Layout ..................................................................... 2.2

Figure 3.1. Proposed Safeguards Design Concept Schematic ........................................................3.3 


\subsection{Introduction}

The International Atomic Energy Agency (IAEA) is tasked with verifying that commitments made by States as part of their safeguards agreements with the IAEA are fulfilled. The IAEA verifies declarations made by States and detects undeclared activities in States through the implementation of a Safeguards Approach (SA) for the facility and a State Level Approach (SLA) for the entire state. At the facility level, the SA consists of measures to verify the nuclear material present and its movement as declared by the facility. The SA measures also provide assurance that the facility operations are as declared and that the facility is not being misused. All these safeguards measures at the facility level contribute to the SLA for the entire state.

"Safeguards by Design" (SBD) is the practice of incorporating features to support application of these measures into facility designs throughout the entire facility lifecycle. The ultimate goal of SBD is to increase the safeguardability of a facility, a qualitative measure of "the degree of ease with which a nuclear energy system can be effectively and efficiently placed under international safeguards" (GIF 2006).

Over the last 20 years, a growing volume of SBD literature has focused on the principles and best practices of the concept. However, these informational and analytical tools have been independently developed with little effort made to form a consistent, structured methodology for a facility designer and its international safeguards experts to use as guidance in assessing the safeguardability of their design. In fiscal year (FY) 2011, the National Nuclear Security Administration's (NNSA's) the Next Generation Safeguards Initiative funded the Pacific Northwest National Laboratory (PNNL), Brookhaven National Laboratory, and several consultants to develop the Facility Safeguardability Assessment (FSA) process to address this need.

FSA is a screening process intended to focus a facility designer's attention on the aspects of their facility or process design that would most benefit from application of the SBD tools. Additionally, the process is meant to identify the necessary guidance within the SBD tools that would have the best application for enhancing the safeguardability of their design. While FSA can be employed throughout the life of a facility, it is intended to be applied during the conceptual (or preliminary) design stage, when many of the design decisions crucial to facility cost and schedule are made.

In FY 2012, NNSA funded PNNL to assess the FSA process by applying it to the conceptual design for a small nuclear power plant being developed by NuScale Power, based in Corvallis, Oregon. Born from a U.S. Department of Energy research project at Idaho National Laboratory and Oregon State University in 2000, the NuScale design is poised to become a likely contender in the predicted energy market for small modular reactors. Having initiated pre-application activities with the U.S. Nuclear Regulatory Commission in 2008, NuScale Power is working to take its design from a concept to a fully commercialized technology, making the design a good candidate for the first trial application of the FSA process. This report documents the application of the FSA process and presents conclusions regarding the efficiency and robustness of the FSA process. It also describes the NuScale safeguards design concept that was developed during the project and presents considerations for safeguardability infrastructure functional guidelines using insights gained from the FSA process. 



\subsection{The NuScale Design}

The NuScale plant design is based upon a modular 45 megawatt electric (MWe) pressurized water reactor (PWR) nuclear power plant. Each NuScale Nuclear Steam Supply (NSS) module, as shown in Figure 2.1, has its own combined containment vessel and reactor system and its own designated turbinegenerator set. NuScale plants are scalable, allowing for a single facility to be filled with anywhere from 1 to 12 modules. In a multi-module plant, one unit can be taken out of service without affecting the operation of the others.

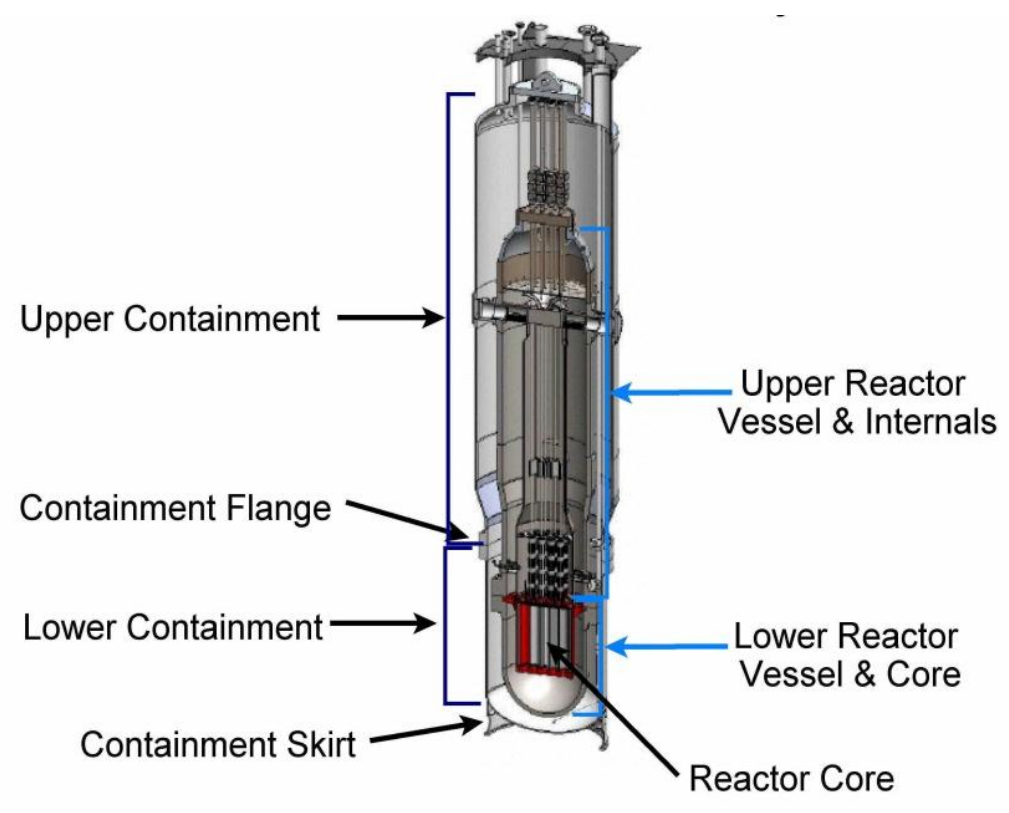

Figure 2.1. Nuclear Steam Supply Module Cutaway Showing Core and Internals

In the NuScale design, the modular unit contains the reactor containment, the reactor vessel, and the primary coolant system (which is circulated by natural convection without reactor coolant pumps), and the steam generators. The design eliminates the need for a conventional emergency core cooling system, employing a passive water cooling system for decay heat removal instead. External piping also provides main feedwater to the steam generators and draws main steam from them, supplying steam to the external turbine generator set that generates electrical power and returns feedwater to the modules.

Each module employs fuel assemblies similar to a standard Westinghouse PWR assembly, except they are approximately half the height. The fuel assembly is a 17 by 17 lattice, containing 289 fuel pins of low enriched uranium (less than 5 weight percent enriched uranium-235). Each NSS module contains 37 fuel assemblies with 16 control rod clusters in two banks - a regulating bank and a shutdown bank.

NuScale modules will be positioned in a reactor hall that is subgrade. In emergency scenarios, the reactor hall pool water can be used as a heat sink should the primary coolant loop fail. As shown in Figure 2.2, the reactor building has multiple stairwells with exterior access to grade, space for technical services, and the reactor control room. The control room is below grade, allowing for maximum working space in the reactor hall to support continual operation. 


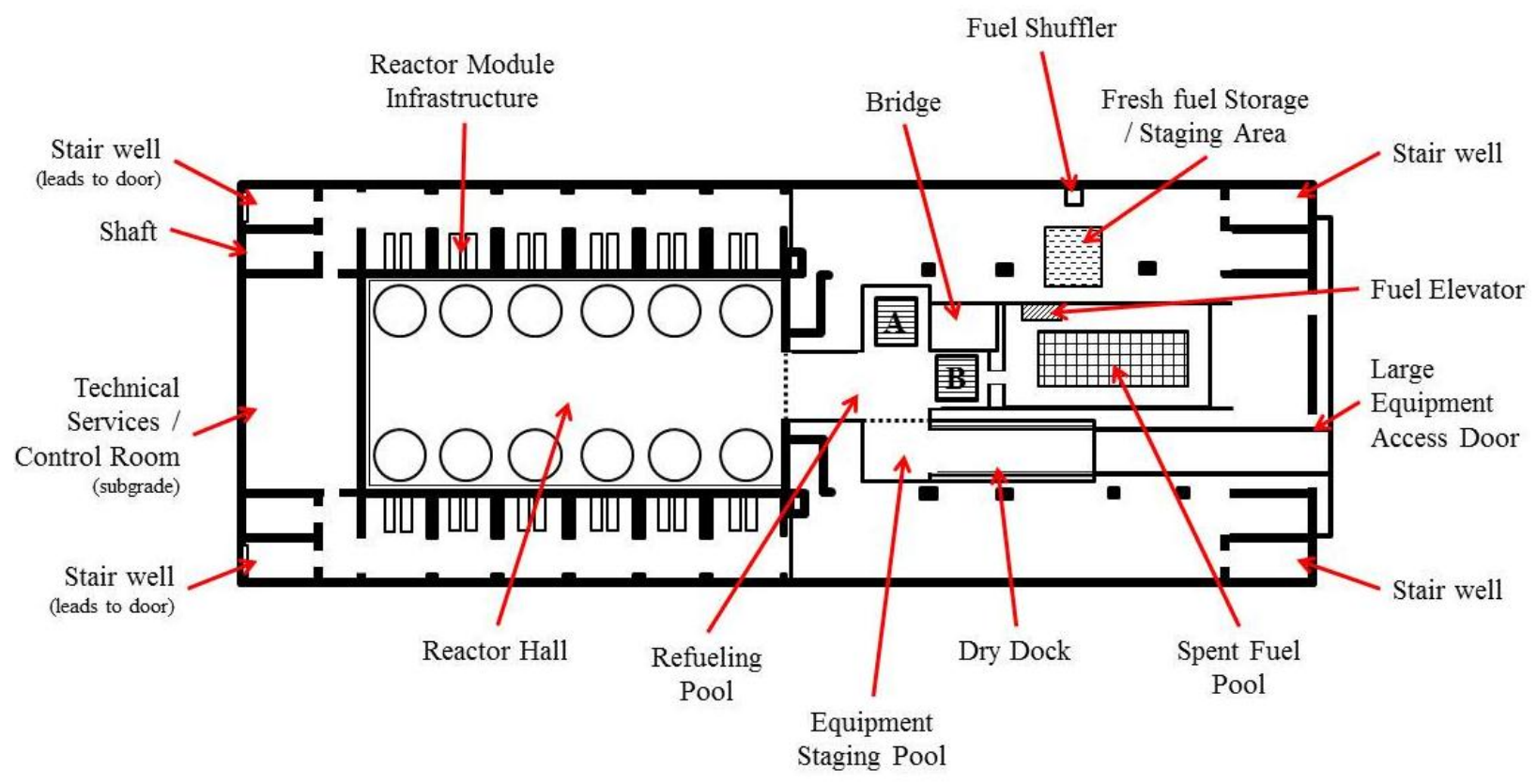

Figure 2.2. NuScale Reactor Building Layout

The refueling pool and fuel storage areas are located opposite the reactor hall. The reactor hall and its pool may be separated from the refueling pool by a gate unless a module is in transit between the pools. The refueling pool has two positions, depicted as A and B in Figure 2.2. During refueling, the containment flange stand, located in position A, is used to remove and store lower containment. In position $\mathrm{B}$, the reactor flange stand supports the lower reactor vessel and reactor core when they are removed for refueling and servicing. Adjacent to refueling position B is the reactor bridge.

Unlike current generation multi-unit PWRs, the NuScale modules are transported to a single pool for refueling. During refueling, the entire NSS module is depressurized, filled with water, isolated, disconnected from external lines, and moved through the water to the refueling pool. Here, reactor containment is disassembled, and the reactor core and control rods are removed and secured in the reactor flange stand. The upper containment and the upper reactor vessel assembly, containing the upper internals (e.g., steam generator) are then moved to a staging area for inspection and maintenance. The reactor core is refueled, first moving fresh fuel from the storage area into the spent fuel storage pool into temporary racks. Using the fuel shuffler, spent fuel is removed from the reactor core to the spent fuel pool, and remaining core fuel is reconfigured to optimize core performance before the fresh fuel is placed in the core. An expanded description of the NuScale design and its operations can be found in Appendix A.

A short channel separates the refueling pool and the spent fuel to accommodate fuel movements underwater. The spent fuel pool contains a fuel elevator that is used to lower fresh fuel assemblies into the spent fuel pool. Adjacent to this fuel elevator is the fresh fuel storage and staging area. Behind this fresh fuel storage area is the fuel shuffler that is used to move fuel between the refueling and storage pool and transfer fuel assemblies into and out of the reactor core. Opposite the fuel shuffler is a dry dock that is connected by rail to the large equipment access door for the reactor building. It is expected that reactor modules, fresh fuel, and spent fuel storage casks will be received through this access door. The dry dock uses a tilting lift action to move NSS modules and spent fuel storage casks from a horizontal position, to a 
vertical position in a staging pool. This small staging pool is separated from the refueling pool by a gate. The design includes a heavy lifting crane (not shown in Figure 2.2) mounted near the roof of the reactor building. The crane is capable of traversing the entire length of the reactor building. This crane is used to move NSS modules.

The anticipated presence of multiple units at a given site is expected to create staggered, frequent refueling operations. A single module is refueled, or has fuel shuffled, once every two years. This staggered approach relies upon a dedicated refueling crew that is part of the plant staff. Spent fuel removed during refueling is stored in the spent fuel pool. This pool has the capacity to store 15 years of accumulated spent fuel assemblies from a 12-module NuScale facility. After approximately 5 years in the pool, the thermal load will be such that the spent fuel assemblies can be moved to a secure dry storage area. The NuScale site layout includes adequate space allocation for the dry cask storage of all of the spent fuel for the 60-year life of the plant. 



\subsection{The FSA Process}

At its core, the FSA process relies upon identification by designers of differences between their proposed facility design and the design of a similar (or reference) facility with an established safeguard approach developed by the IAEA. For this case, the chosen reference facility is a typical current generation 1000 MWe PWR. A detailed description of this reference facility and its safeguards approach can be found in Appendix B.

A detailed description of the FSA process can be found in Bari et al. 2012. At a high level, the FSA process consists of four steps:

1. use of the FSA screening tool to identify aspects of the new design that may create issues for the application of international safeguards when compared to the reference facility

2. development of SDC describing suggested safeguards measures for the new design using SBD tools

3. completion of a simple diversion pathway analysis to evaluate the effectiveness of proposed SDC

4. reporting of lessons learned about the proposed SDC and a preliminary assessment of the safeguardability of the new design.

\subsection{Application of the FSA Process to the NuScale Design}

A completed FSA screening tool that expresses consolidated responses of the authors to the specific questions can be found in Appendix C. From the responses, design differences of significance to international safeguards arise from

- the dimensions of the NuScale fuel assemblies

- the anticipated presence of a large number of SMR units at a single site

- the centralized refueling process employed for the NuScale design.

Since NuScale uses shorter fuel assemblies, the individual fuel pins are smaller. This means approximately twice as many fuel pins must be diverted by an adversary in order to acquire a significant quantity of special fissionable material (SFM). Additionally, the shorter assemblies allow the spent fuel to be stored in a two-high stack in the spent fuel storage pool. Unless appropriate design features are provided, this stacking approach limits, or precludes, direct visual and physical access to the bottom fuel assemblies without rearrangement of the fuel stack. This stacking has the potential to impede inspector verification of the spent fuel inventory and places an increased burden upon the operator during inspector verification activities if fuel must be shuffled to gain access to the lower assemblies.

In multiple module plants, the staggered refueling cycle complicates implementation of international safeguards because there is not a single point in time where fuel assemblies in all modules are accessible for visual inspection and/or non-destructive assay (NDA) measurements. Additionally, execution of traditional IAEA inspections during refueling would be costly for the IAEA because refueling activities would be occurring frequently, requiring a frequent inspector presence at the facility. 
The single, centralized refueling area, while similar to traditional PWRs, can be expected to have frequent activity. The safeguards measures applied to this central area must maintain continuity of knowledge (CoK) of fissile material that is moving between the module being refueled and the spent fuel storage pool without hindering facility operations.

Further consideration of these design differences gives rise to the following challenges to the implementation of international safeguards that need to be resolved by the SDC:

- challenge of maintaining CoK of NSS module status during movement of NSS modules from the reactor hall to the common refueling area

- difficulty in physical inventory verification and interim inventory verification because there is no time in normal operation when all fuel assemblies in the entire facility would be accessible to inspectors

- increased complexity of inventory verification because frequent refueling of modules creates the possibility that a module could be refueled between the taking of a physical inventory and its verification

- difficulty in physical inventory taking and verification of spent fuel assemblies that are at the bottom of a double stack of assemblies.

\subsection{Safeguards Design Concept}

As mentioned in the previous section, although the NuScale design is similar to that of the commonly safeguarded PWR, the use of multiple modules within a single facility and the frequent refueling scheme require a modified approach to implementing international safeguards. To address the challenges mentioned in Section 3.1, elements of SAs for off-load and on-load fueled type reactors were considered by the authors in the development of an SDC for the NuScale design.

The SDC, as developed by the authors and illustrated in Figure 3.1, maintains CoK through the use of containment and surveillance, item accountancy, and Short-Notice and No-Notice Random Inspections (SNRI/NNRIs). As an item facility, NuScale will rely upon the accounting of individual items of fuel and verification of the item's identity and integrity. The frequent state of refueling means an extensive C/S scheme can be employed to monitor, or reconstruct, facility operations at times when an IAEA inspector is not present. It is expected that any $\mathrm{C} / \mathrm{S}$ or monitoring system employed will have the capability to allow unattended and remote monitoring. This capability will complement mailbox declaration submissions of fuel transfers as a part of the implementation of SNRI/NNRIs.

In the author-developed SDC, the biological buffer above each NSS module is sealed with an active tamper-indicating device (TID). The biological buffer, rather than the reactor containment or reactor vessel, was chosen as the location for the seal because the buffer must be removed before a module can be moved from its operating position. By sealing the buffer, the seal can still be easily accessible to an inspector and monitored by surveillance in the reactor hall. Inside the reactor building, there are four camera units that will monitor the reactor hall (C1), the refueling and spent fuel pools (C4), and the large equipment access door (C3). One surveillance unit (C2) is attached to the fuel shuffler to enable the IAEA to verify serial numbers on fuel assemblies as they are moved, as well as record core layouts of each NSS module for comparison between refueling and for inventory taking and verification. 


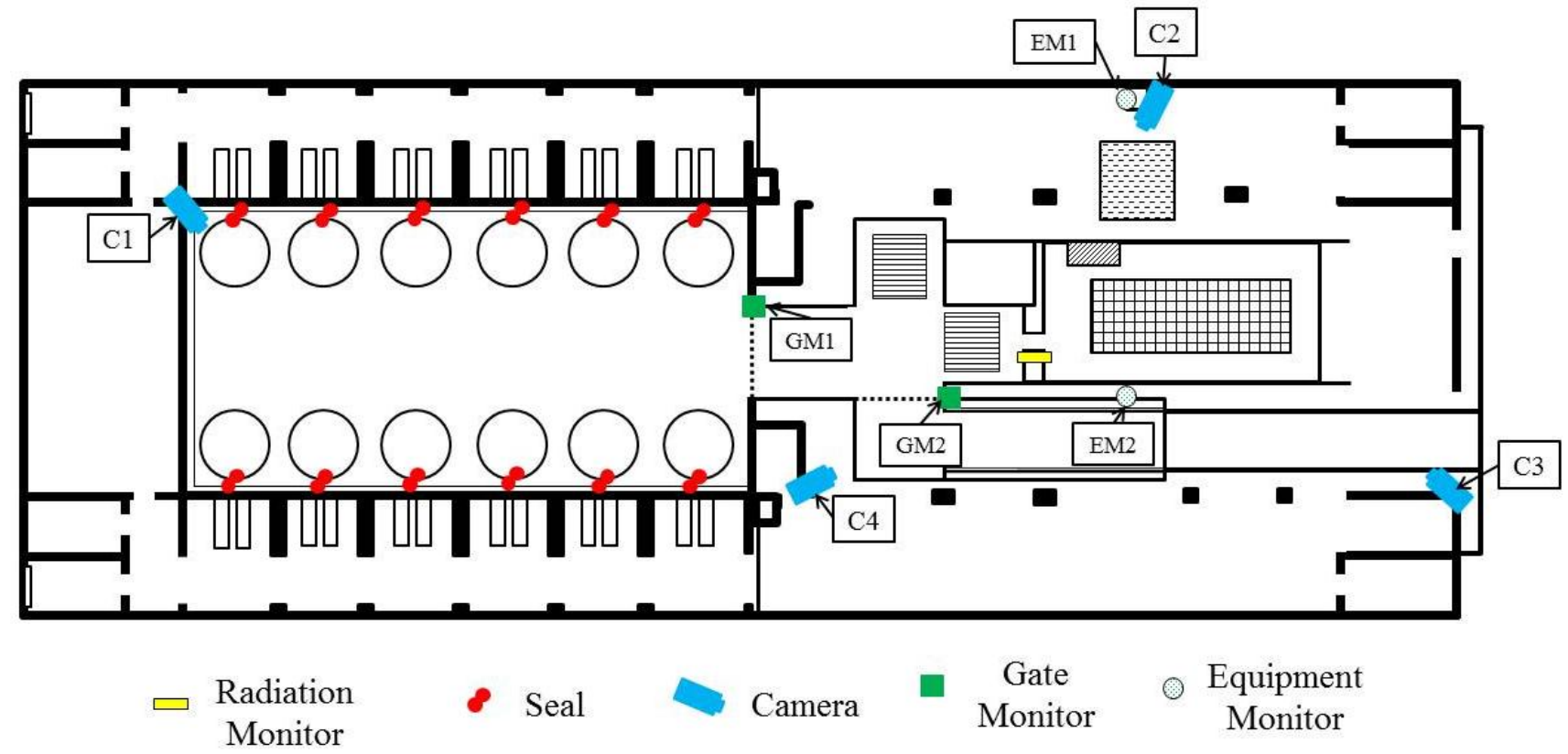

Figure 3.1. Proposed Safeguards Design Concept Schematic

To monitor movements between the various pools, each gate that separates the reactor hall, refueling pool, and equipment staging pool will have a gate monitor (GM1-GM2) capable of sensing when each gate is opened. These monitors are not meant to restrict access to the gates, only to record when the gates were opened or closed.

There is a radiation monitor between the fuel storage pool and the refueling pool. This monitor would operate as a "yes/no" radiation detector to simply indicate when material was being transferred between the two pools. Using this monitor, the IAEA would be able to verify when fuel was moved.

An equipment monitor is placed on the fuel shuffler (EM1), dry dock lift (EM2), and heavy lift crane. This monitor is used to verify when the equipment is in use. The monitor could be as simple as a power indicator that would log when power was turned on or off for the piece of equipment, or a combination of measures that would also log equipment position.

In addition to the $\mathrm{C} / \mathrm{S}$ measures, like traditional PWRs, the SDC will employ nuclear material accountancy measures (item counting and item verification), review of operating records and reports, design information verification, and physical inventory verification. The operator is responsible for maintaining facility operation records that the IAEA would verify using the C/S measures and nuclear material accountancy. The operator will also be responsible for determining the amount of plutonium produced and fissile material depleted in each fuel assembly based on these operating records.

The reactor building is designed to have multiple exterior access points since containment is local to each NuScale module. It is anticipated that physical protection measures would be implemented at these access points, or personnel doors, and would complement implemented international safeguards measures. 


\subsection{Simple Pathway Analysis}

The robustness of the author-developed SDC for NuScale was assessed by performing a simple proliferation pathway analysis. Five diversion scenarios from Technical Report Services (TRS) 392 (1998) were considered:

1. removal of fuel rods or assemblies from the fresh fuel storage area

2. removal of fuel assemblies from a module core

3. irradiation of undeclared fuel assemblies or other materials in or near a module core, and removal of the material from the facility

4. removal of fuel rods or assemblies from the spent fuel

5. removal of fuel rods or assemblies from a consignment when or after they leave the facility.

The removal of fresh fuel rods or assemblies from the fresh fuel storage area would require substitution with dummy assemblies or rods and the falsification of records. This diversion pathway could be hindered by the application of seals to the fresh fuel shipping containers and surveillance of fuel removal from shipping containers. However, this is unlikely as an inspector must be present to apply the seals at the shipping facility and detach the seals at the receiving facility, requiring a greater inspector presence at each facility. Use of a random sampling plan to perform NDA measurements on fresh fuel assemblies as part of the SNRI/NNRI more efficiently deters a diversion of this type. Furthermore, the fresh fuel storage area and fuel pool are under surveillance, which provides an increased detection probability with this diversion strategy.

In order to remove fuel assemblies from one of the module cores, an adversary would have to substitute diverted assemblies as well as falsify operating and accounting records. Unique to the NuScale design are the multiple reactor cores from which fuel can be diverted. This presents two scenarios, one where an adversary could divert fuel from a module in the reactor hall or from a module that is in the refueling pool. The SDC has been designed to address each scenario. Undetected diversion from a module in the reactor hall is obstructed with the application of a seal to the biological buffer above each NSS module, in addition to cameras positioned in the reactor hall. In the case of a diversion in the refueling pool, the pool is designed to accommodate a single module at a time. The entire area is maintained under surveillance and as fuel is moved between each pool area, a radiation monitor provides an indication of fuel movement activities. For any assemblies that have been removed from a core, use of NDA techniques, such as the Cerenkov Viewing Device (CVD) or the fork detector, would provide additional information about the fuel assembly history and integrity.

The irradiation of undeclared fuel assemblies or targets in one of the NSS modules, and their subsequent undetected removal, has a low probability of success because this pathway would require defeat of seals applied to biological barriers and surveillance positioned throughout the facility. Furthermore, radiation monitors positioned at access points to the reactor building further complicate undetected removal of irradiated assemblies or targets from the facility. Falsification of operation and accounting records and reports and defeat of reactor hall surveillance cameras would also be required if the assembly or target was removed at a time other than refueling of a NSS module. In the case of a reactor positioned for refueling, the cameras and equipment monitor on the fuel shuffler would require use of additional equipment that cameras could be used to detect. 
Removal of fuel rods or assemblies from the spent fuel pool could be concealed with the use of dummy assemblies or rods and the falsification of operating and accounting records. The NuScale design decreases the difficulty of some aspects of this diversion, in comparison to the current PWR design, and presents additional challenges to its detection because of the double stacking of fuel assemblies in the fuel pool. Since fuel on the lower level would be difficult to visually count and inspect, an adversary could replace these assemblies with dummies that would not be detected until spent fuel assemblies were removed for shipment from the facility or placed within a storage casks. This is countered in the SDC with surveillance of the spent fuel pool. Furthermore, if access to lower assemblies is possible, use of NDA measurements as part of a random sampling plan would increase the probability of detection of substitution of assemblies. Additionally, any use of gates between pools or equipment in the dry dock would indicate a change in operations that would alert an inspector to investigate further.

Diversion of fuel rods or assemblies during transport to or from the NuScale facility requires concealment by substituting assemblies and falsifying accounting records. Dummy assemblies could be moved to or from the fuel storage pool during unloading or loading of shipping containers. Countermeasures against this type of diversion could include the application of seals to shipping containers prior to shipment to or from the reactor facility. However, it is more efficient to verify assembly identity and integrity for fresh assemblies when received at the reactor as part of SNRIs/NNRIs and spent fuel assemblies shipped from the reactor at receipt at a reprocessing facility or repository.

In each of the diversion scenarios reviewed, the proposed SDC provided for a high probability that the actions of the adversary would be detected within the same timeliness goals for detection of diversion (three months for low enrichment uranium [LEU] core and 12 months for fresh LEU fuel and spent fuel sited at a reactor facility). Based on the current understanding of the NuScale design and FSA as performed, in comparison to diversion scenarios found in a typical light water reactor (LWR) facility, the NuScale design does not present any new, unique diversion scenarios.

\subsection{Functional Guidelines for NuScale Design}

During the last phase of the project, the authors considered functional "infrastructure" guidelines for the NuScale design. These guidelines can be considered analogous to the use of voluntary standards or regulatory guidance to ensure adequate safety in design. However, these functional guidelines are meant to be sufficient to ensure safeguardability in the design. Building from general guidance found in TRS 392 (1998) and insights gained from the FSA screening tool, applicability of guidance is examined for development of functional infrastructure guidelines to ensure safeguardability of the NuScale design. For space reasons, these considerations can be found in Appendix D. 



\subsection{Lessons Learned for FSA}

The successful application of the FSA process to the NuScale design generated the following lessons learned, which are discussed in more detail in the following sections.

1. Designers would benefit from accessible training materials on key safeguards terms and concepts to facilitate the completion of the FSA screening tool.

2. Infrastructure functional guidelines would augment the FSA process, making it more useable to a designer.

3. There is sufficient information available during the conceptual/preliminary design phase for effective application of the FSA process.

4. Despite the shift in focus to functional infrastructure guidelines, the development of the safeguards design concept remains a vital part of the FSA process.

5. There is limited utility in having the designer conduct a path analysis of the safeguards design concept, particularly with the IAEA engaged early in the design process.

6. Additional guidance is needed to help designers interpret safeguards guidance in the tool box.

7. Coordination with designers requires a structured approach early in the process.

\subsection{Safeguards Training Materials Would Facilitate Completion of the FSA Screening Tool}

An analyst thoroughly familiar with IAEA safeguards, and many of the guidance documents in the SBD toolbox, would have likely been able to identify many of the safeguards challenges without using the FSA screening tool. However, the FSA screening tool is meant to be completed by a design team that may include facility designers who are unfamiliar with international safeguards. Therefore, it would be useful to develop or leverage existing training material on safeguards concepts and terminology for facility designers and project managers.

\subsection{Infrastructure Functional Guidelines Augment the FSA Process, Leading to Designs with Greater Flexibility to Accommodate Evolving Safeguards Technologies}

$\mathrm{NuScale}$ designers expressed a desire for a set of functional design requirements that would ensure safeguardability as technologies evolved. So, the FSA process was augmented to move beyond the development of the SDC (as initially planned). As safeguardability is a qualitative measurement of the ease of implementation of safeguards measures, additional work was completed to address the applicability of general safeguards design guidelines found in TRS 392 (1998) to the NuScale design. Since the guidelines address only the infrastructure that the facility needs to provide, a design meeting these guidelines will support implementation of a range of IAEA safeguards approaches. So long as the infrastructure elements are conservatively designed, the approach may yield a design that supports upgrades as safeguards technology improves or supports changes to specific safeguards measures as determined by the IAEA. 


\subsection{FSA is Applicable During the Conceptual/Preliminary Design Phase}

One of the concerns when this trial was initiated was whether there would be sufficient information available during the conceptual/preliminary ${ }^{1}$ design phase for fruitful application of the FSA process . The FSA analysis was performed using non-proprietary NuScale design information at a level of detail consistent with a facility preliminary design. This resulted in some uncertainties regarding specific facility operations when the SDC was developed. Regardless, because the guidelines are focused on what the facility must provide (i.e., the infrastructure to support types of safeguards equipment) rather than what the IAEA establishes (e.g., the specific safeguards equipment to be installed), they support and facilitate a fairly wide range of safeguards approaches, which can be refined as the design progresses. However, it should be noted that the NuScale design has many similarities to current PWR designs, which allowed the authors to make fairly reliable assumptions about the way that the design would evolve. The FSA process may not work as well at the conceptual/preliminary design stage for designs that are more revolutionary.

\subsection{Despite the Shift to Infrastructure Functional Guidelines, the Development of the Safeguards Design Concept Remains a Vital Part of the FSA Process}

The extension of the FSA process has shifted the focus from the development of the SDC to the development of facility infrastructure guidelines. This shift of focus may raise questions about the overall utility of developing a representative SDC that may differ significantly from the safeguards approach that the IAEA ultimately chooses to require. However, the process of developing and reviewing the SDC provided vital insights for adapting the general guidelines to the NuScale design. The discussion in Appendix D identifies the specific areas where the SDC influenced the adaptation of guidelines to the $\mathrm{NuScale}$ design. It is likely that the development of the SDC would be even more valuable for designs that were more revolutionary than the NuScale design.

\subsection{There is Limited Utility in Having the Designer Conduct a Path Analysis of the Safeguards Design Concept}

The focus of the path analysis was to determine whether there were any paths that the SDC did not appear to adequately address. Thus, the process was extremely qualitative. The quality of such a path analysis is an aspect of the FSA process that is quite dependent upon analyst experience and understanding of safeguards measures and their vulnerabilities. If FSA is to be used by designers, depending upon the team composition this may necessitate additional training for designers targeted in these areas. However, the training would largely focus on the vulnerabilities of safeguards measures and misuse strategies. The development of training in these areas that is both effective and accessible is problematical. Although the path analysis provides additional confidence in the comprehensiveness of the safeguardability guidelines, it is not essential to their development. With IAEA engagement early in

\footnotetext{
${ }^{1}$ The terms conceptual design and preliminary design do not have a common definition in domestic and international documents. The combined term is used to refer to conceptual design as defined in DOE Order 413.3B, "Program and Project Management for the Acquisition of Capital Assets," with the understanding that this same design stage may be referred to as preliminary design in other documents.
} 
the design process, the most prudent approach may be to eliminate the path analysis by the designer, recognizing that the IAEA review and analysis provides high assurance of completeness and comprehensiveness.

\subsection{Additional Guidance for Designers is Needed to Help Interpret Safeguards Guidance}

The documents in the safeguards tool box, particularly Design Measures to Facilitate Implementation of Safeguards at Future Water Cooled Nuclear Power Plants (IAEA 1998), contained information that was extremely useful. The main limitation was that the information was located throughout several sections of the documents, was not consistently presented in the form of requirements, and focused more on specific safeguards measures and approaches. It would be useful to develop additional guidance on the infrastructure that the facility needs to provide to support safeguards measures and approaches. That would make it much easier for the designers to extract the applicable requirements as a part of the FSA process. It would also help ensure that application of the FSA process would support the development of a design that readily accommodates a wide range of safeguards measures rather than being tailored to specific safeguards measures.

\subsection{Coordination with Designers Requires a Structured Approach}

NuScale feedback on the value and application of the FSA approach was critical to the success of the project. However, there were significant coordination challenges associated with time, funding, and management of potentially proprietary information that delayed progress. For future trial applications where vendor participation is desired, it would be useful to have agreements for non-disclosure and other information protection established at the start of the project, more clearly defined expectations for vendor participation, and funding for vendor support established at the beginning of the task. In this case, $\mathrm{NuScale}$ representatives have reviewed the report to verify that it does not contain proprietary information, but they have taken no position agreeing or disagreeing with the assessment of the functional guidelines, or the conclusions and lessons learned. 



\subsection{Conclusion}

The trial application of the FSA process demonstrated its basic utility during the conceptual/preliminary design phase for a small modular reactor with similarities to current PWR designs. We believe the process demonstrated that the development of safeguardability functional guidance for facility designers would significantly enhance the potential flexibility and utility of the approach. We also believe the process requires a reasonable level of effort on the part of the designers, making it more likely that the process will be used on future designs. Our experience applying the FSA approach illustrated the need for additional guidance and training to make the process more approachable for designers. This experience also illustrated the desirability of supplemental guidance related to design requirements for the infrastructure that a facility needs to provide to support possible IAEA safeguards approaches. A valuable next step in FY 2013 is to have NuScale designers conduct a detailed review of the FSA process. Such a review could provide additional insights about the practical utility of the FSA approach and the flexibility and robustness of the process. 



\subsection{References}

Bari RA, J Hockert, EF Wonder, III, SJ Johnson, R Wigeland, and MD Zentner. 2012. Overview of the Facility Safeguardability Analysis (FSA) Process. PNNL-21698, Pacific Northwest National Laboratory, Richland, WA.

DOE Order 413.3B. 2010. "Program and Project Management for the Acquisition of Capital Assets." U.S. Department of Energy, Washington, DC. Available at https://www.directives.doe.gov/directives/0413.3-BOrder-b/at_download/file.

IAEA International Atomic Energy Agency. 1998. Design Measures to Facilitate Implementation of Safeguards at Future Water Cooled Nuclear Power Plants. Technical Reports Series No. 392, International Atomic Energy Agency, Vienna, Austria.

GIF The Proliferation Resistance and Physical Protection Evaluation Methodology Expert Group of the Generation IV International Forum. 2006. Evaluation Methodology for Proliferation Resistance and Physical Protection of Generation IV Nuclear Energy Systems. GIF/PRPPWG/2006/005, Revision 5, OECD Nuclear Energy Agency.

NuScale Plant Design Overview, NP-ER-0000-1198, Rev. 0, NuScale Power, LLC, Corvallis, Oregon, August 2012, accessed at http://pbadupws.nrc.gov/docs/ML1221/ML12216A392.pdf.

NuScale Refueling Operations Report, NP-DEM-RP-RFOP-002-NP, NuScale Power, Inc., Corvallis, Oregon, March 2009, accessed at http://pbadupws.nrc.gov/docs/ML0908/ML090850080.pdf.

Pan, Paul, Scott DeMuth, Mark Mullen, Preliminary Analysis of Safeguards and Security by Design for Small Modular Reactors (SMRs), Los Alamos National Laboratory, Los Alamos, NM, August 2011.

Reyes, Dr. J.N., “Overview of NuScale Technology," presented at IAEA Workshop on Technology Assessment of Small and Medium-sized Reactors (SMRs) for Near Term Deployment, Vienna Austria, 2011, accessed at http://www.iaea.org/NuclearPower/Downloads/Technology/meetings/2011-Dec-5-9WS-SMR/Day-2/15_USA_Reyes_NuScale_SMRDec2011.pdf.

Reyes, Dr. J.N., “Overview of NuScale Technology,” presented at I-NEST Fuel Cycle CORE Workshop, Corvallis, OR February 21, 2012, accessed at https://inlportal.inl.gov/portal/server.pt/document/104522/11__reyes?qid=02332043\&rank=1.

Reyes, Dr. Jose N., "Meeting Introduction and Overview of NuScale Design," NP DEM PM 0000004, presented at U.S. Nuclear Regulatory Commission Pre-Application Meeting, Rockville MD, April 2009, accessed at http://pbadupws.nrc.gov/docs/ML0908/ML090850077.pdf.

Reyes, Jr., Dr. José N., "Meeting Introduction and Overview of NuScale Design," briefing presented to U.S. Nuclear Regulatory Commission, Rockville, MD, April 2, 2009, accessed at http://pbadupws.nrc.gov/docs/ML0908/ML090850077.pdf. 
Snuggerud, Ross, "NuScale Refueling Process," NP-DEM-PM-RFOP-003-NP, briefing presented to U.S. Nuclear Regulatory Commission, Rockville, MD, April 2, 2009, accessed at http://pbadupws.nrc.gov/docs/ML0908/ML090850079.pdf. 


\section{Appendix A}

\section{Expanded NuScale Design Information for FSA Review}





\section{Appendix A}

\section{Expanded NuScale Design Information for FSA Review}

This report provides a preliminary facility design description for the NuScale design concept. It is intended for use in assessing the safeguardability of the NuScale design, using the Facility Safeguards Assessment (FSA) screening process. This information is based solely upon publicly available design information, provided in the referenced sources ${ }^{1}$ and may not represent current design parameters.

\section{A.1 Facility Description}

\section{A.1.1 NuScale Plant Layout}

The conceptual layout for a 540 MWe site with 12 NuScale modules is shown in Figure A.1. As shown, there is a central reactor hall containing the $12 \mathrm{NuScale}$ modules. The two inner buildings that surround the reactor hall contain the 12 turbine generator units powered by the modules. The two buildings outside of the turbine generator units contain the cooling towers that provide the ultimate heat sink for the steam condensers. The basic plant parameters are shown in Table A.1.

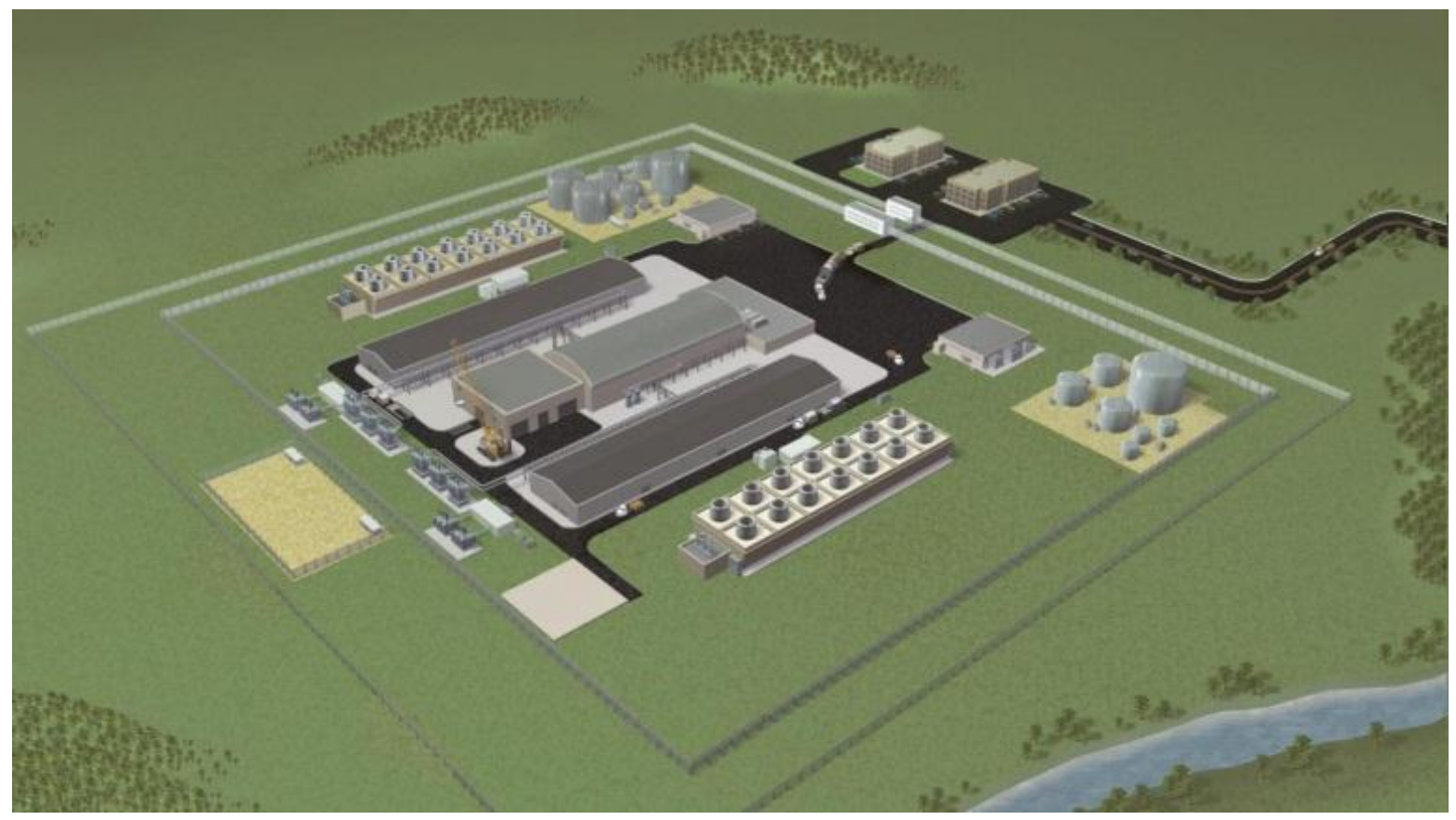

Figure A.1. Site Layout for 12 Module NuScale Plant (from Reyes 2012d)

\footnotetext{
${ }^{1}$ It has, however, been reviewed by NuScale Power, LLC to ensure that no proprietary information has been presented.
} 
Table A.1. Basic Plant Parameters (from Lorenzini 2012, Welter and Linik. 2012)

\begin{tabular}{|c|c|}
\hline \multicolumn{2}{|c|}{ Overall Plant } \\
\hline Net Electrical Output & $540 \mathrm{MW}(\mathrm{e})$ \\
\hline Number of Power Generation Units & 12 \\
\hline Nominal Plant Capacity Factor & $>90 \%$ \\
\hline \multicolumn{2}{|c|}{ Power Generation Unit } \\
\hline Number of Reactors & One \\
\hline Net Electrical Output & $45 \mathrm{MW}(\mathrm{e})$ \\
\hline Number of Steam Generators & Two independent tube bundles \\
\hline Steam Generator Type & Vertical helical tube \\
\hline Steam Cycle & Slightly Superheated \\
\hline Turbine Throttle Conditions & $3.1 \mathrm{MPa} / 264^{\circ} \mathrm{C}\left(450 \mathrm{psia} / 507^{\circ} \mathrm{F}\right)$ \\
\hline Turbine Type & $3600 \mathrm{rpm}$, single pressure \\
\hline Steam Flow & $71.3 \mathrm{~kg} / \mathrm{s}(565,723 \mathrm{lb} / \mathrm{hr})$ \\
\hline Feedwater Temperature & $149^{\circ} \mathrm{C}\left(300^{\circ} \mathrm{F}\right)$ \\
\hline \multicolumn{2}{|c|}{ NSS module } \\
\hline Thermal Power Rating & $160 \mathrm{MWt}$ \\
\hline Cold Leg / Hot Leg Temperature & $247.9^{\circ} \mathrm{C} / 288.85^{\circ} \mathrm{C}\left(478.1^{\circ} \mathrm{F} / 551.9^{\circ} \mathrm{F}\right)$ \\
\hline Coolant Mass Flow Rate & $\sim 700 \mathrm{~kg} / \mathrm{s}$ \\
\hline Operating Pressure & $8.72 \mathrm{MPa}(1850 \mathrm{psia})$ \\
\hline \multicolumn{2}{|c|}{ Reactor Core } \\
\hline Fuel & UO2 (<4.95\% enrichment) \\
\hline Number of Fuel Assemblies & $\begin{array}{l}37 \text { assemblies / } 16 \text { control rod clusters in two } \\
\text { banks (a regulating bank and a shutdown bank) }\end{array}$ \\
\hline Fuel Assembly Design & $17 \times 17$ lattice ( $1 / 2$ height for standard PWR fuel) \\
\hline $\begin{array}{l}\text { Number of Fresh Fuel Assemblies in an } \\
\text { IAEA Significant Quantity (75 Kg U-235) }\end{array}$ & 6 Assemblies (1584 fuel rods) \\
\hline $\begin{array}{l}\text { Number of Spent Fuel Assemblies in an } \\
\text { IAEA Significant Quantity }(8 \mathrm{Kg} \mathrm{Pu})\end{array}$ & 4 Assemblies (1056 fuel rods) \\
\hline
\end{tabular}




\section{A.2 General Description}

The NuScale module is an integrated light water reactor (LWR) with passive safety features and a power rating of approximately $45 \mathrm{MWe}(160 \mathrm{MWt})$. The pressurizer, steam generator, hot leg, cold leg, and core are all housed in a shared reactor pressure vessel. A relatively small steel containment envelops the reactor pressure vessel. The containment vessel is partially evacuated during power operation and is capable of relatively high pressures during accident conditions. The entire module and containment are submerged in a pool of water. The reactor pool is a stainless steel-lined concrete pool shared by all of the operating modules. Figure A.2 shows a schematic of a NuScale module. The module is covered by a biological shield, and all of the modules and pool are enclosed in a single confinement building.

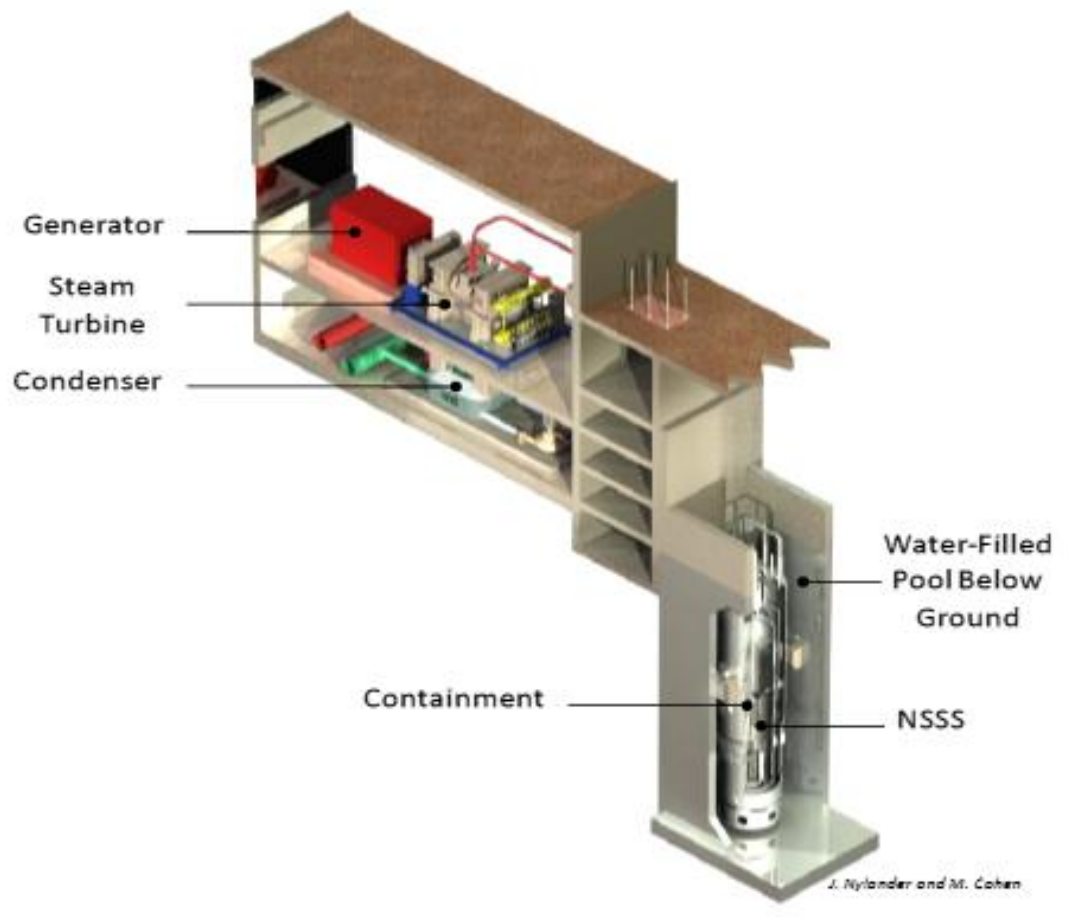

Figure A.2. NuScale Module (from Reyes 2012d)

The NuScale design relies on passive safety systems and incorporates all large piping paths into the reactor vessel. The use of passive safety systems for decay heat removal, emergency core cooling, and containment cooling eliminate external power requirements under accident conditions. The NuScale modules, control room, and spent fuel pool are all located below grade and housed in controlled-access buildings.

The core is located inside a shroud connected to the hot leg riser. Sub-cooled water enters the core, where it is heated and then flows vertically into the riser section. Circulation continues as hot water exits the riser into the upper plenum and then turns downward into the annulus housing the steam generators. Hot water in the annulus between the riser and the inside wall of the reactor vessel is cooled by the steam generator tubes. The cooled, denser water descends through the downcomer into the lower plenum, then re-enters the core (NuScale 2012c). 


\section{A.2.1 Reactor Core}

The NuScale module's reactor core consists of 37 fuel assemblies arranged in a 17 x 17 square array. The core includes 16 control rod clusters. Each fuel assembly includes 264 fuel pins, 24 control rods, and one instrument tube (NuScale 2012c). The fuel rods are approximately one half the height of standard pressurized water reactor (PWR) fuel and operate at a lower power density (45-65 KW/L) than current PWRs. The fuel is enriched to less than 4.95 percent in uranium-235 and is designed to support a minimum 24-month cycle (i.e., refueling every two years) with a 95 percent capacity factor (Welter 2012).

\section{A.2.2 Reactor Pool}

The reactor pool consists of a large, below-grade concrete pool with a stainless steel liner that provides stable cooling for the containment vessel for a minimum of 72 hours following any LOCA. During normal plant operations, heat is removed from the pool through a closed loop cooling system and ultimately rejected into the atmosphere through a cooling tower or other external heat sink. In an accident where offsite power is lost, heat is removed from the reactors and containments by allowing the pool to heat up and boil. Water inventory in the reactor pool is large enough to cool the reactors for at least 30 days without adding water. After 30 days, passive air cooling of the containments provides adequate cooling for long-term decay heat removal (NuScale 2012b).

\section{A.2.3 Fuel Handling and Reactor Maintenance Areas}

The fuel handling and reactor maintenance areas include space for

- new fuel storage

- spent fuel pool

- refueling pool

- dry dock.

The fuel handling and maintenance areas are housed within the reactor building and consist of belowgrade pools and dry, above-grade areas. The pools include the refueling pool, spent fuel pool, and dry dock. Above-grade areas provide space for the operation of handling equipment, access to the upper portion of modules while the reactor core is being refueled, and space for the storage of new fuel assemblies.

The refueling pool is connected directly to the reactor pool via a canal able to accommodate underwater transport of the module. A fuel canal between the refueling pool and spent fuel pool provides passage for fuel assemblies during the refueling process. The fuel handling and maintenance areas are designed to provide radiation protection for plant operation and maintenance personnel who are working in those areas.

The new fuel storage area contains a fuel receiving area, new fuel storage racks, and a jib crane for loading dry new fuel assemblies into the new fuel elevator. The area has forklift access for new fuel 
receiving as well as access for a cask transporter to support the preparation and movement of spent fuel to dry storage.

The spent fuel pool provides storage space for up to 15 years of accumulated spent fuel assemblies, temporary storage for new fuel assemblies. During refueling, new fuel assemblies are moved from dry storage and temporarily stored in racks in the spent fuel pool before being placed in the reactor core. After being removed from the reactor core, spent fuel assemblies are placed in spent fuel storage racks in the spent fuel pool. Within approximately 5 years, the thermal load of the spent fuel assemblies is reduced significantly, and the assemblies can be moved to a secure dry storage area. The plant site layout includes space allocation adequate for the dry storage of all of the spent fuel for the 60-year life of the plant.

The refueling area houses the equipment to disassemble and reassemble the module during refueling. The reactor core is stored in a specially designed fixture in the reactor pool while spent fuel is removed, fuel is shuffled, and new fuel is placed. A traveling bridge fuel-handling machine moves new and used fuel through a submerged access path between the refueling pool and spent fuel pool.

The dry dock area is separated from the refueling pool by a gate. With the dry dock gate closed, pool water can be removed and maintenance activities can be completed in the dry dock. This area includes the necessary inspection and testing equipment needed for the modules. Introduction of a new module into the reactor building pool system and module maintenance takes place in the dry dock. The dry dock provides maintenance access to the upper section of the containment vessel and reactor pressure vessel. The dry dock is also used for placing new module components into the reactor building pool system and preparing them for assembly. Additionally, it provides access for shipment of used modules offsite (NuScale 2012b).

\section{A.3 Refueling Process Description}

The NuScale Nuclear Steam Supply (NSS) modules sit in a borated pool that is common to all modules. Refueling of the modules occurs in a separate pool attached to the containment cooling pool by a central canal. This allows refueling operations to occur separately and distant from the operating modules. During refueling the two pools are isolated from each other using a gate or installed weir. Refueling the reactor in a separate pool allows refueling equipment and activities to have a permanent location. This simplifies the refueling process and will contribute to more consistent outage performance (Lorenzini 2012).

\section{A.3.1 Module Disconnection}

With the containment vessel flooded, the reactor vent and recirculation valves open, and the primary system temperature stable, the protective covers over the module bay are removed. These covers are segmented to support disassembly and storage. These moves will be performed by the single-failureproof transfer crane. With the module exposed, the transfer crane and lifting rig are attached to the module prior to any disassembly activities (NuScale 2012d).

The module is secured and working platforms are installed in order to allow access to the steam and feedwater connections (see Figure A.3). The lines to the feedwater system, steam system, and the 
connections to other systems external to the module are disconnected and capped on the module and the external systems (Snuggerud 2012).

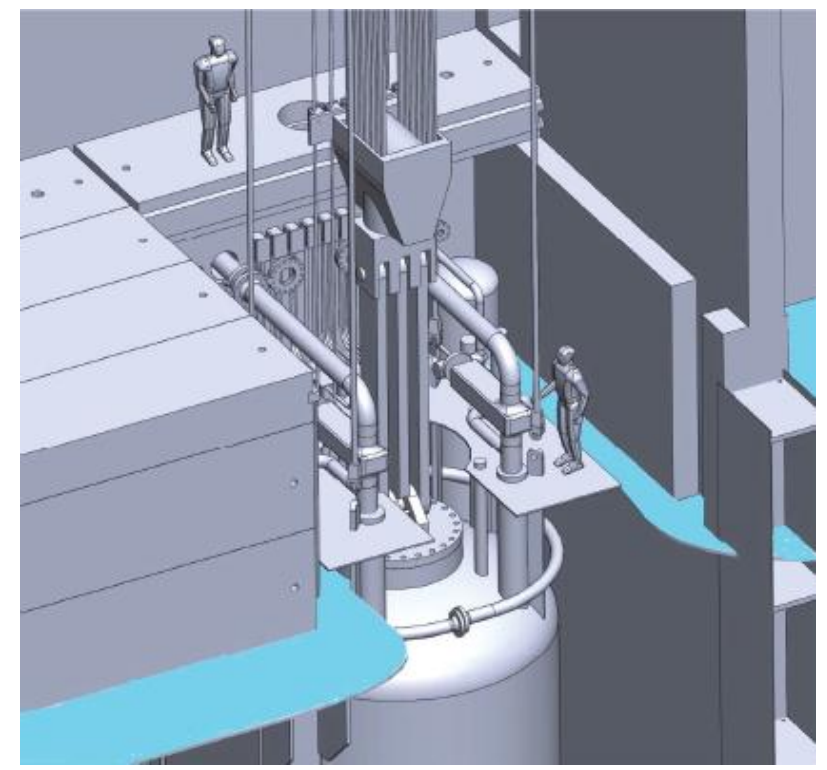

Figure A.3. Configuration for Module Disconnection (Reyes 2012c)

Finally, to support module transfer, the trunnion caps are removed. The trunnions support the module from docks on the bay walls during operation. The trunnion caps lock the containment vessel trunnions in place during operation (see Figure A.4). Once the vessel has been attached to the crane, these caps can be removed, and the vessel is ready for transfer (NuScale 2012d).
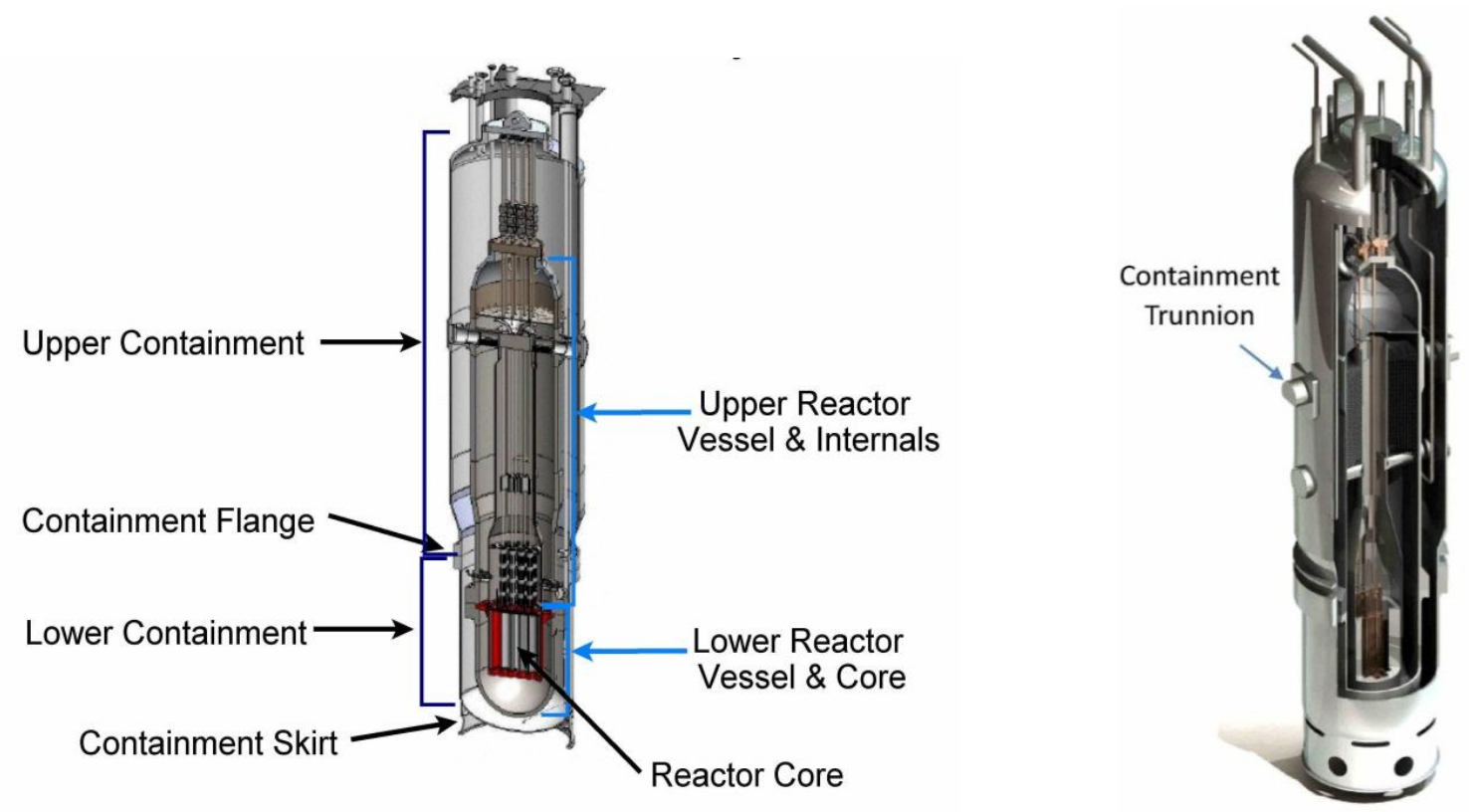

Figure A.4. NSS Module Cutaway (on left) Showing Core and Internals (Reyes 2012b), and Cutaway (on right) Showing Containment Structure Trunnion (LaFountain 2012). 


\section{A.3.2 Module Transport}

The movement of the reactor and containment vessel to a refueling location is a unique feature of the NuScale concept. The transfer crane is used to lift the vessel, transit to the refueling pool, seat the containment on the containment flange, and align with the containment flange disassembly rig. Alignment with the disassembly rig is verified using match marks, interlocks, and cameras (NuScale 2012d). Figure A.5 depicts the placement of the components during transport by the crane.

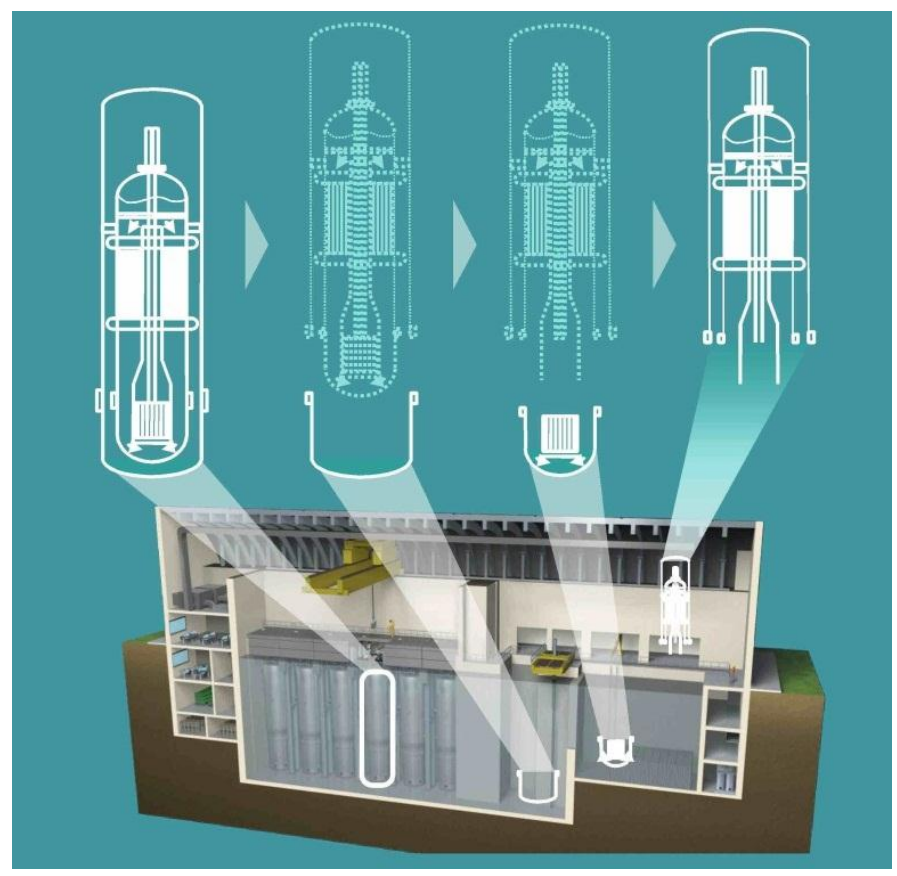

Figure A.5. Summary Refueling Schematic (Reyes 2012d)

\section{A.3.3 Module Disassembly and Refueling}

The disassembly rig is used to disassemble the containment flange and the reactor vessel and the upper containment are moved to the reactor flange stand. The reactor flange is opened and the lower reactor vessel, including fuel and control rods, is moved into the refueling position. The upper containment and the the upper reactor vessel and internals (Figure A.6) are moved to the test pit. The test pit is used for testing of the helical steam generators and other reactor internals. The reactor core is refueled using the shuffler, which moves fresh fuel assemblies (from the spent fuel pool) into the core, rearranges the fuel assemplies in the core to optimize the neutron flux profile, and remove spent fuel from the reactor core to the spent fuel pool (Snuggerud 2012). 


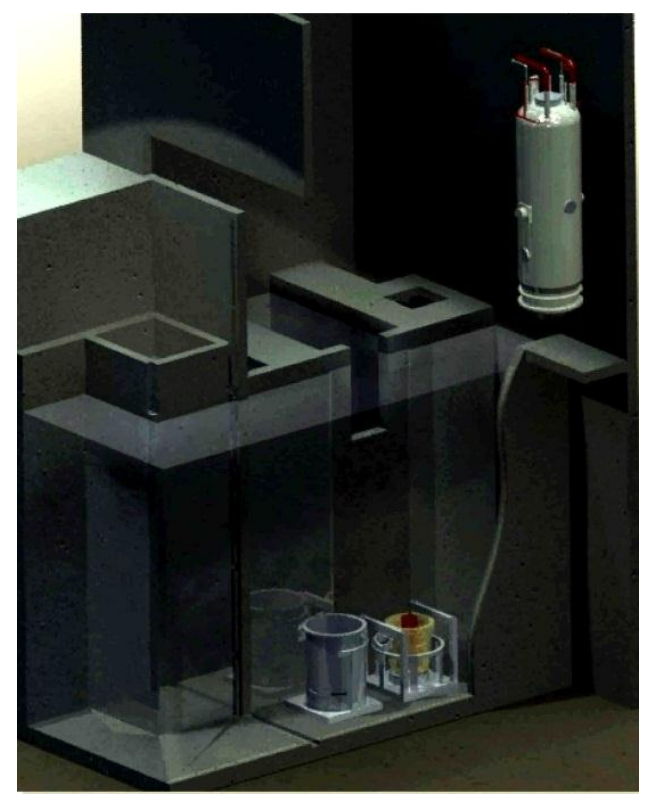

Figure A.6. Lifting the Upper Containment and Internals (Reyes 2012a)

\section{A.3.4 Module Restoration}

Restoration is the reverse of the disassembly process. The upper containment and upper reactor vessel and internals are moved from the test pit and mated with the refueled core and lower reactor vessel on the reactor flange stand. The reactor flange is reassembled to join the two. The upper containment and reactor vessel are moved to the containment flange stand, in the refueling pool, and mated with the lower containment. The containment flange is reassembled to mate the two. The correct reassembly and sealing of both the reactor and containment flanges are verified in the refueling pool. Once this verification has been completed, the module is transferred from the disassembly rig to the crane and returned to its operating area. The module remains attached to the crane until the lines to the feedwater system, steam system, and the connections to other systems external to the module have been restored. The containment remains flooded until the steam generators are returned to service. The containment is then drained and the containment vacuum is restored (Snuggerud 2012).

\section{A.4 References}

LaFountain M. 2012. "Containment Functions, Requirements, and Capabilities.” October 2011. Accessed September 25, 2012 at http://adamswebsearch2.nrc.gov/webSearch2/main.jsp?AccessionNumber='ML112980493'.

Lorenzini P. 2012. “NuScale Power Introduction.” Presented to the U.S. Nuclear Regulatory Commission, Rockville Maryland, November 20, 2008. Accessed September 24, 2012 at http://adamswebsearch2.nrc.gov/webSearch2/main.jsp?AccessionNumber='ML083460391'.

NuScale. 2012a. "How NuScale Technology Works.” Accessed on September 24, 2012 at http://www.nuscalepower.com/ot-How-NuScale-Technology-Works.php. 
NuScale. 2012b. "NuScale Plant Design Overview.” NP-ER-0000-1198, NuScale Power, Inc., Corvallis, Oregon, August 2012. Accessed September 25, 2012 at http://pbadupws.nrc.gov/docs/ML1221/ML12216A392.pdf.

NuScale. 2012c. "NuScale Preliminary Loss-of-Coolant Accident (LOCA) Thermal-Hydraulic and Neutronics Phenomena Identification and Ranking Table (PIRT).” NP-TR-0610-289-NP, NuScale Power, Inc., Corvallis, Oregon, 2010. Accessed on September 24, 2012 at http://pbadupws.nrc.gov/docs/ML1018/ML101810013.pdf.

NuScale. 2012d. "Refueling Operations Report for the NuScale Power Module." NP-DEM-RP-RFOP002-NP, Rev. 0, March 2009, NuScale Power, Inc., Corvallis, Oregon. Accessed September 25, 2012 at http://pbadupws.nrc.gov/docs/ML0908/ML090850080.pdf.

NuScale Power. 2012. “Overview of NuScale's Technology.” Accessed September 25,2012 at http://www.nuscalepower.com/ot-Scalable-Nuclear-Power-Technology.php.

Reyes JN. 2012a. "Introduction to NuScale Design.” Presented to the U.S. Nuclear Regulatory Commission, Rockville, Maryland, July 24, 2008. Accessed September 25, 2012 at http://nuscalepower.com/pdf/NRC_preapp_mtg_072408_DESIGN_2_no_animation_.pdf.

Reyes JN. 2012b. "Meeting Introduction and Overview of NuScale Design.” NP-DEM-PM-0000-004, presented at the U.S. Nuclear Regulatory Commission Pre-Application Meeting, Rockville Maryland, April 2, 2009. Accessed September 25, 2012 at http://pbadupws.nrc.gov/docs/ML0908/ML090850077.pdf.

Reyes JN. 2012c. "NuScale Technology Overview," presented at the U.S. Nuclear Regulatory Commission Pre-Application Meeting, Rockville Maryland, June 2, 2010. Accessed September 25, 2012 at http://adamswebsearch2.nrc.gov/webSearch2/main.jsp?AccessionNumber='ML101520622'.

Reyes JN. 2012d. "Overview of NuScale Technology." Presented at the IAEA Workshop on Technology Assessment of Small and Medium-sized Reactors (SMRs) for Near Term Deployment, Vienna, Austria, 2011. Accessed September 24, 2012 at http://www.iaea.org/NuclearPower/Downloads/Technology/meetings/2011-Dec-5-9-WSSMR/Day-2/15_USA_Reyes_NuScale_SMRDec2011.pdf.

Snuggerud, R. 2012. "NuScale Refueling Process." NP-DEM-PM-RFOP-003-NP, presented at the U.S. Nuclear Regulatory Commission Pre-Application Meeting, Rockville Maryland, April 2, 2009. Accessed September 25. 2012 at http://pbadupws.nrc.gov/docs/ML0908/ML090850079.pdf.

Welter K. 2012. “NuScale Technology Overview.” Presented at the U.S. Nuclear Regulatory Commission Pre-Application Meeting, Rockville Maryland, December 13, 2010. Accessed on September 25,2012 at http://adamswebsearch2.nrc.gov/webSearch2/main.jsp?AccessionNumber='ML103470495'. 
Welter K and L Linik. 2012. "NuScale Fuel Solution.” Presented to the U.S. Nuclear Regulatory Commission, Rockville, Maryland, May 2012. Accessed September 24, 2012 at

http://adamswebsearch2.nrc.gov/webSearch2/main.jsp?AccessionNumber='ML12125A114'.

Landrey, Bruce T., "Introduction to NuScale Power," presentation at The 4th Annual Asia-Pacific Nuclear Energy Forum on Small and Medium Reactors (SMRs): Benefits and Challenges, Berkley

Nuclear Research Center, 2010, accessed at http://bnrc.berkeley.edu/documents/forum2010/Presentations/F-Session-I-P/Bruce_Landrey_NuScale_Pres.pdf. 


\section{Appendix B}

\section{Reference Pressurized Water Reactor Description}





\section{Appendix B}

\section{Reference Pressurized Water Reactor Description}

\section{B.1 Draft Reference Plant Safeguards Approach}

This section describes the safeguards approach for the reference plant, a pressured water reactor with four steam generators and primary cooling loops. The safeguards approach focuses on the activities within the Reactor Containment (Building 1) and the Fuel Building (Building 4) in Figure B.1, because these locations are where most of the special fissionable material (SFM) is used or stored. This appendix discusses the fuel (NM) -handling activities and the facility safeguards approach to provide a reference for comparison with the NuScale design, using the Facility Safeguardability Assessment (FSA) methodology presented in the main body of this report. 


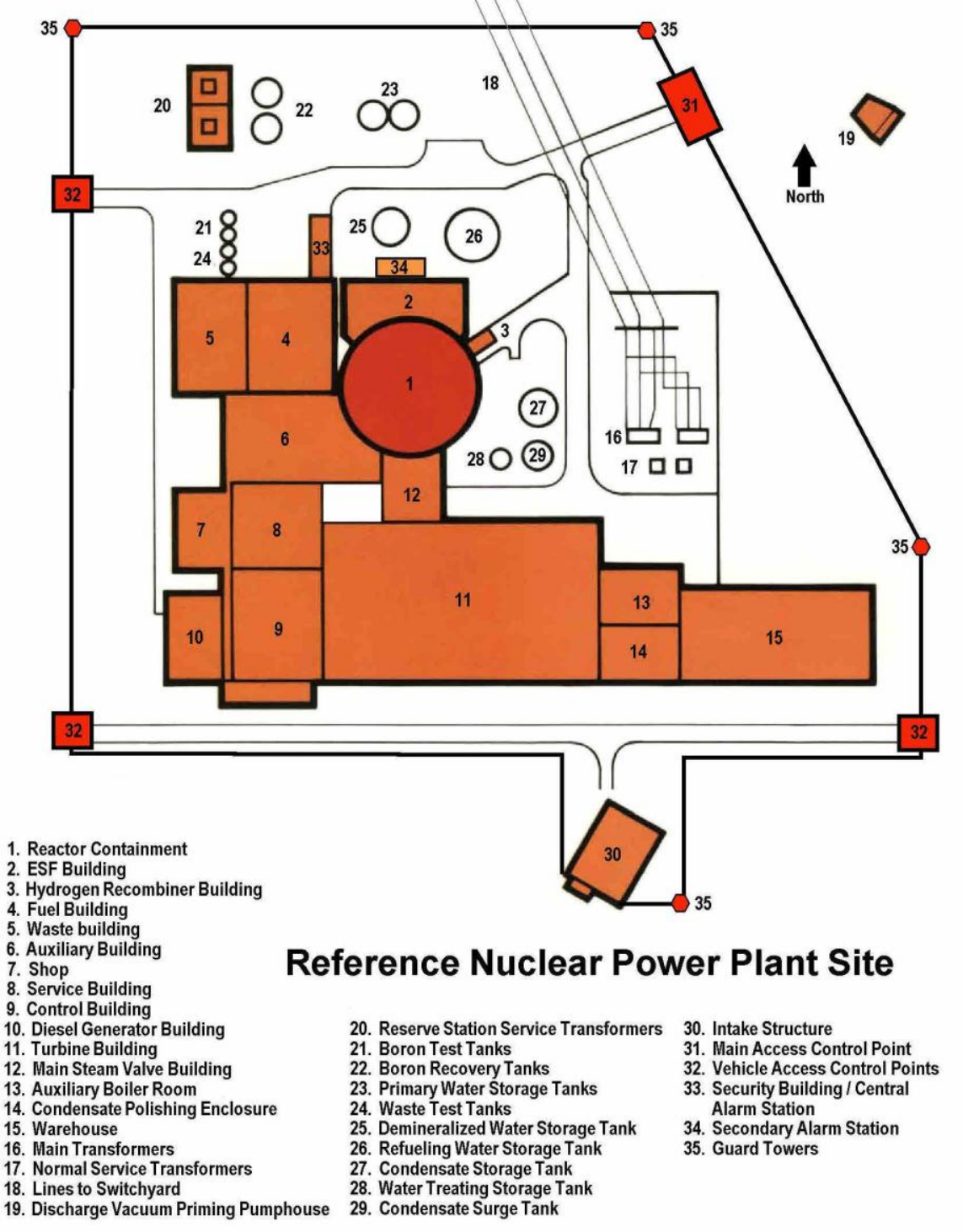

Figure B.1. Reference Nuclear Power Plant Site Layout

\section{B.2 Fuel Handing}

New fuel assemblies normally arrive at the site shortly before refueling is to commence. The assemblies are received into the Fuel Building shown in Figure B.2. The fuel assemblies are received in the receiving area, near where the new fuel casks are staged (Area 3 in Figure B.2). 


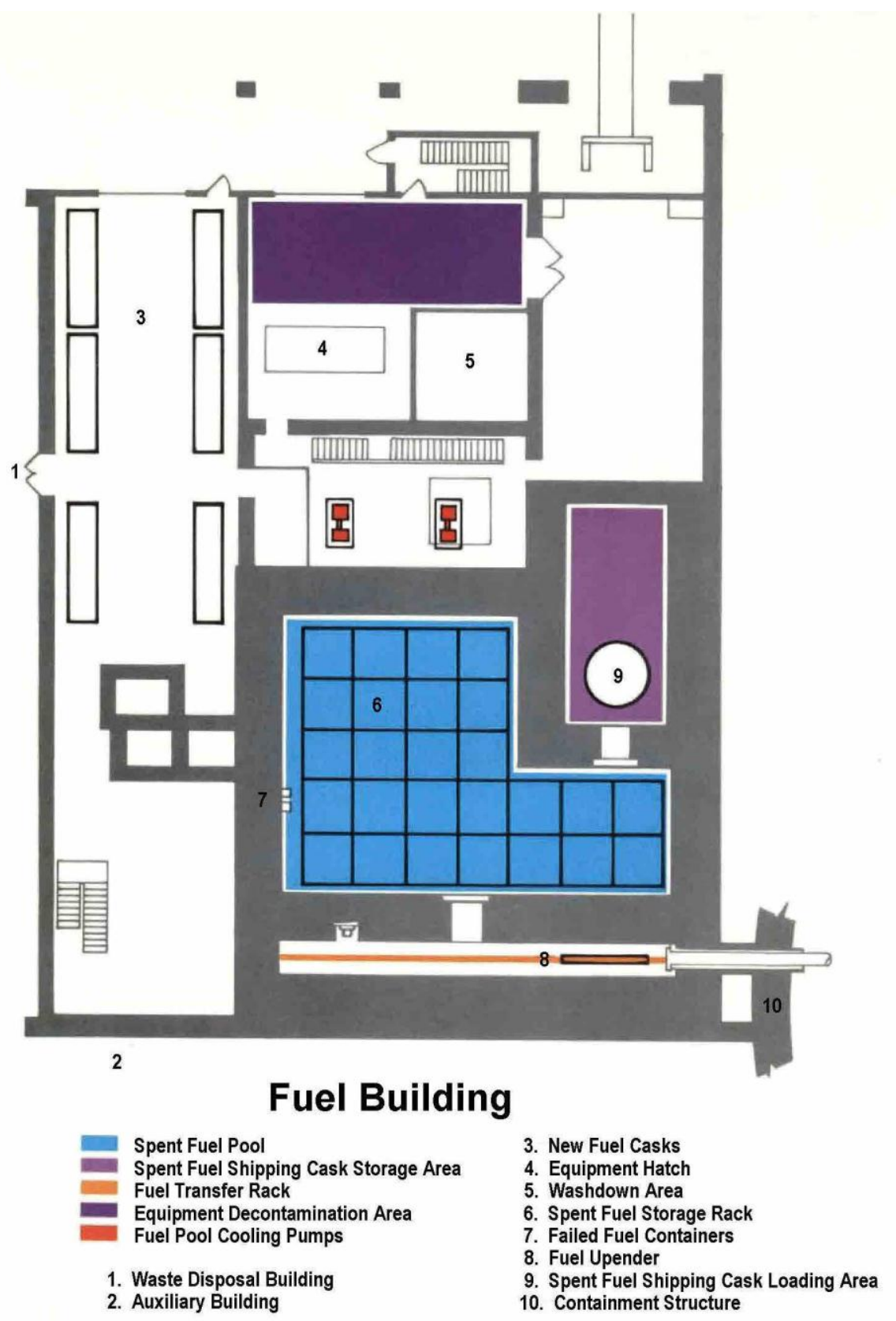

Figure B.2. Fuel Building Layout

The overall configuration of the fuel assemblies is shown in Figure B.3. The fuel rods in an assembly are arranged in a square array with 17 rod locations per side or 289 rod locations per assembly (some assembly designs may have fewer fuel rods). Of the 289 possible rod locations, 264 actually contain fuel rods. The other 25 locations are filled by 24 guide tubes for the rod cluster control assemblies (control rods) and one guide thimble for in-core nuclear instrumentation. Each fuel rod contains uranium oxide fuel pellets. The uranium-235 enrichment in the fuel assemblies is 2.1, 2.6, or 3.1 weight percent. The varying uranium enrichments help ensure uniform neutron flux throughout the active area of the reactor core. (The higher enriched fuel assemblies are loaded around the boundary of the core.) A core loading consists of 193 fuel assemblies. Each fuel assembly contains about 1,154 pounds of uranium oxide. With 
the zircaloy clad and other mechanical components, each fuel assembly weighs about 1,500 pounds, three quarters of a ton.

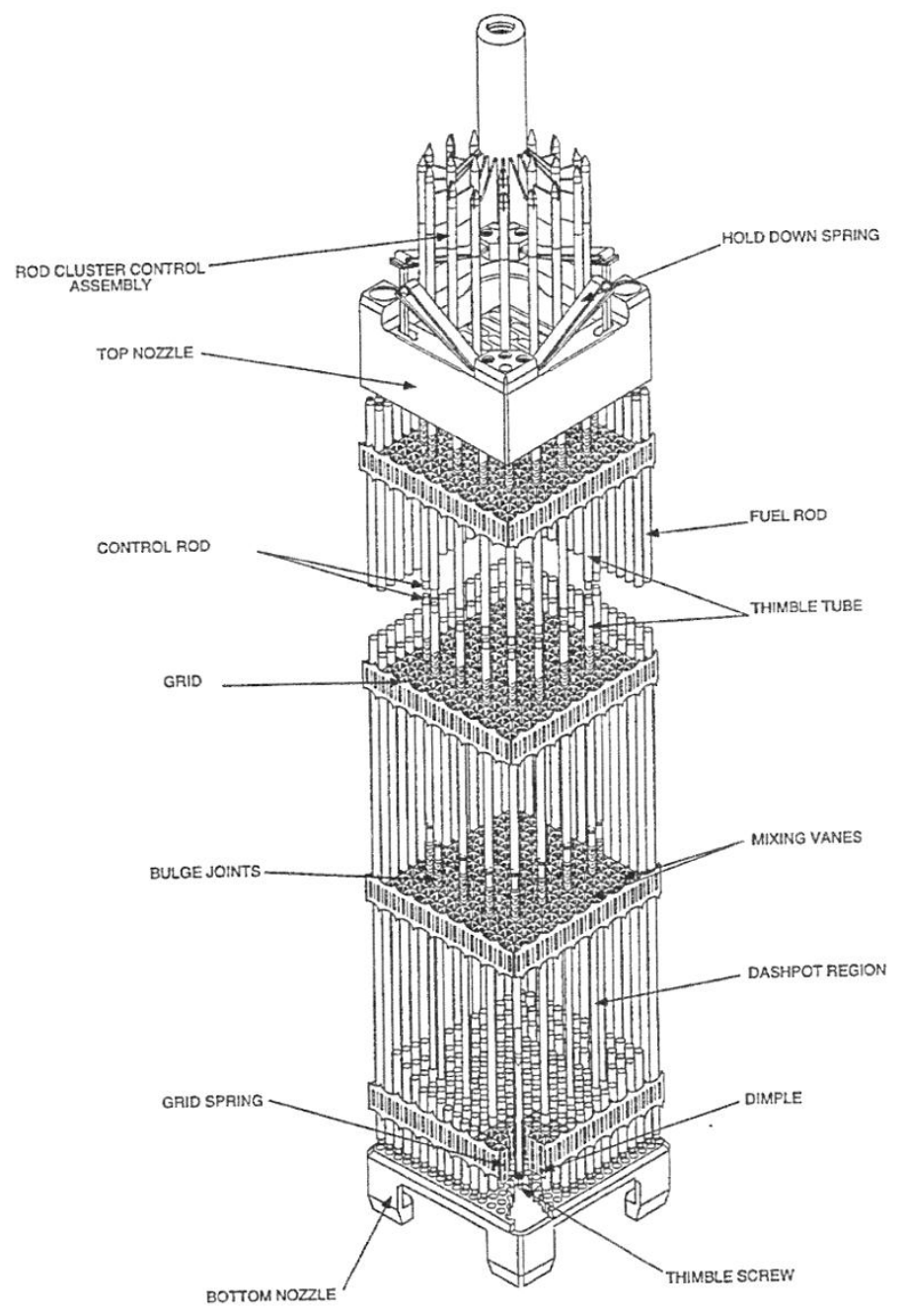

Figure B.3. Cutaway of a Typical Fuel Assembly with Control Rod

Refueling is accomplished during reactor shutdown. The fuel handling facilities (Figure B.4 and Figure B.5) are generally divided into two areas:

- the spent fuel pool, which is kept full of water and is always accessible to operating personnel

- the refueling cavity and the fuel transfer canal, which are flooded only during the refueling shutdown. 


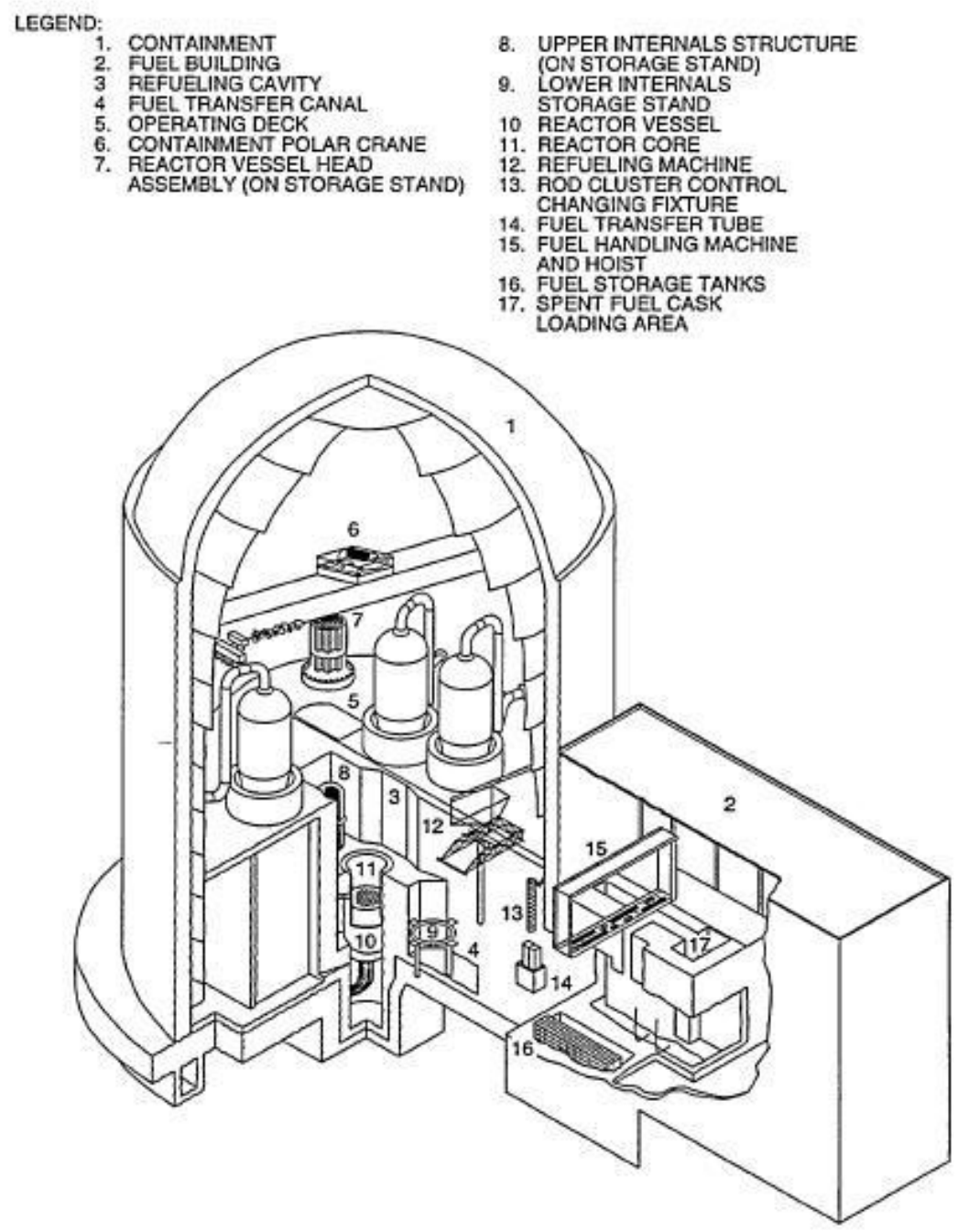

Figure B.4. Reactor Containment Showing Refueling Cavity and Fuel Transfer Canal 


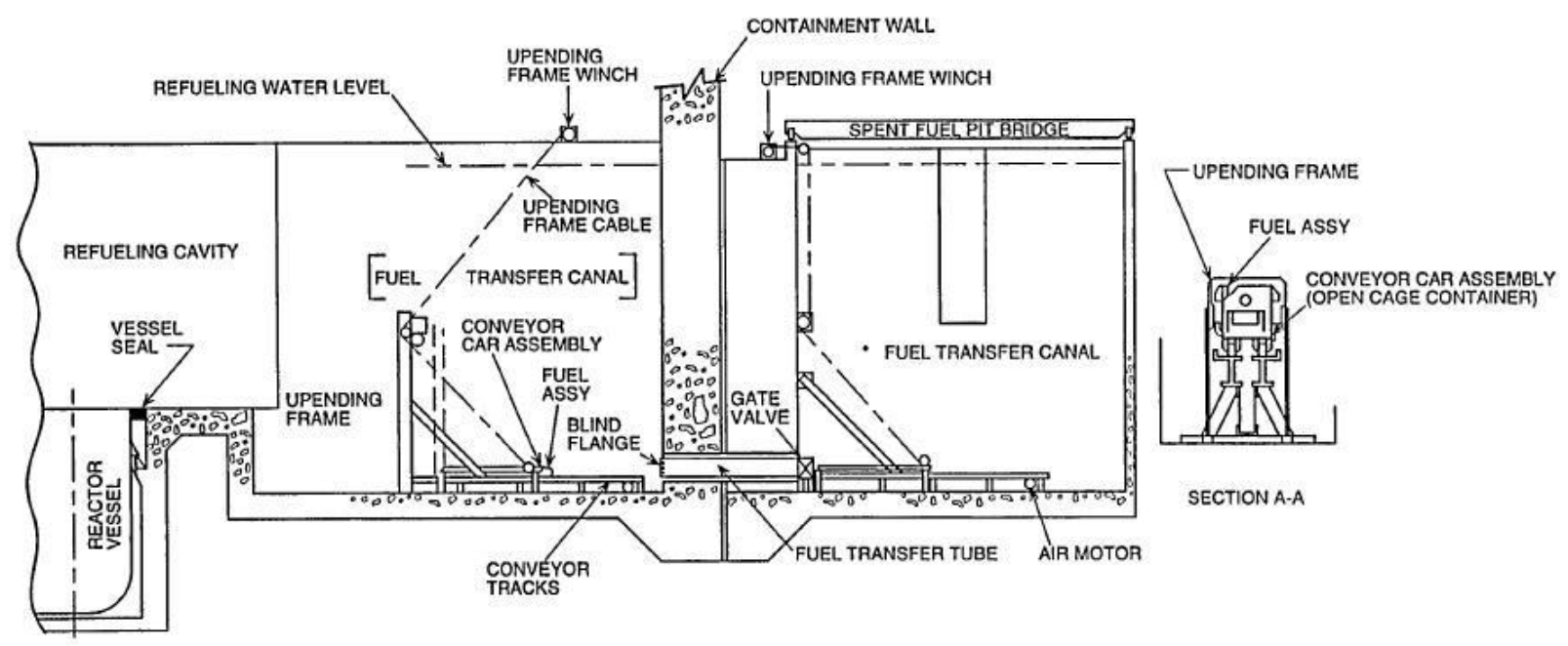

Figure B.5. Fuel Transfer System

\section{B.3 Refueling Process}

These two areas are connected by the fuel transfer tube through which an underwater conveyor or fuel transfer system carries the new fuel into the plant (reactor) containment and spent fuel into the fuel building. Spent fuel is handled underwater from the time it leaves the reactor vessel until it is placed in a cask for shipment from the site. The water provides an effective, economical, and transparent radiation shield as well as a reliable medium for decay heat removal. Boric acid is added to the water to ensure subcritical conditions during refueling.

New fuel assemblies normally arrive at the site shortly before refueling commences. A typical fuel shipment on a flatbed trailer consists of six containers each containing two new fuel assemblies. A piggyback rail shipment would carry two such flatbed trailers. The fuel assemblies are secured to a shock-mounted strong-back, located inside the container and are shipped in the horizontal position. Upon receipt, the facility verifies the integrity of the shipping container and tamper-indicating devices and compares the fuel assembly item numbers with the shippers manifest. The receipt inspection also checks for possible shipping damage to the fuel assemblies. The new fuel assemblies are then lowered into the spent fuel pool by means of the new fuel elevator, located on the side of the spent fuel canal, and are placed underwater in the storage racks. During the refueling operation, the new assemblies are transported from their storage locations in the pit to the fuel transfer system by means of the fuel handling machine and the spent fuel handling tool.

The spent fuel pool provides for the underwater storage of spent fuel assemblies and new fuel assemblies in the fuel storage racks. New fuel assemblies are stored in casks in the fuel building and transferred to the underwater fuel storage racks prior to transfer to the reactor during under refueling. The spent fuel pool is constructed of reinforced concrete, and the entire interior surface is lined with stainless steel plate. Because there are no gravity drains in the pit, it cannot be drained accidentally. Cooling to remove residual decay heat from the spent fuel is provided by a spent fuel pit cooling and cleanup system. 
Spent and new fuel assemblies are handled manually by a spent fuel assembly handling tool suspended from an overhead hoist and manipulated by an operator standing on a movable bridge over the pit.

Fuel assembly storage racks to accommodate a minimum of approximately $133 \%$ the number of assemblies in a core are located on the pit floor. Fuel assemblies are placed in vertical cells, continuously grouped in parallel rows. The racks are designed to preclude insertion of fuel assemblies in other than the prescribed locations, thereby maintaining the necessary spacing between assemblies. The racks thus provide a subcritical geometric array. Borated water is used to fill the pit to a concentration matching that used in the refueling cavity during refueling, and to a depth sufficient to allow transfer of the fuel assemblies while providing adequate water cover for shielding.

The fuel transfer canal is a passageway that extends from the refueling cavity to the inside surface of the reactor containment. The canal is formed by concrete shielding walls extending upward to the same elevation as the refueling cavity. A portion of the floor of the canal is at a lower elevation that the refueling cavity. This provided the extra depth needed for the fuel system upending device and the rod cluster control changing fixture located in the canal. The transfer tube, which connects the fuel transfer canal to the fuel building, is sealed at both ends except during refueling.

The fuel transfer system incorporates an underwater conveyor car that runs on tracks extending from the fuel transfer canal through the transfer tube in the containment wall and into the fuel building. The car is driven by a pusher arm connected to two continuous roller chains. The roller chains are driven by an electric motor mounted near the operating floor of the spent fuel pool and connected to the chain drive sprockets by a vertical drive shaft.

The conveyor car (upender) container accepts a fuel assembly in the vertical position. It is rotated to a horizontal position for passage through the fuel transfer tube and is then rotated to a vertical position for unloading. The upending operation is the same in both the fuel building and the containment transfer canals.

During plant operation, the conveyor car is stored in the fuel building. A gate valve in the transfer tube on the fuel building end is closed to seal the reactor containment. The terminus of the tube inside the containment is seal by a blind flange.

\section{B.3.1 Refueling Operation}

The refueling operation is divided into five major phases: preparation, reactor disassembly, fuel handling, reactor reassembly, and preoperational checks, tests, and startup. Step-by-step descriptions through the five phases of a typical refueling operation are given in the following sections.

\section{B.3.1.1 Phase I - Preparation}

1. The reactor is shut down and cooled to ambient conditions.

2. A radiation survey is performed and the containment is entered.

3. The fuel transfer equipment and refueling machine are checked out. 


\section{B.3.1.2 Phase II - Reactor Disassembly}

1. The control rod drive mechanism cooling fans and air ducts are disconnected and moved to storage.

2. The control rod drive mechanism missile shield is removed and stored.

3. The reactor vessel head insulation is removed.

4. The control rod drive mechanism cables are disconnected.

5. The upper instrumentation thermocouple leads are disconnected. The thermocouple column protective sleeve is installed over the top of the support column.

6. Seismic support tie bars, cable tray assemblies, and missile shield support beams are removed.

7. In-core instrumentation thimble guides are disconnected at the seal table and extracted.

8. Reactor vessel head nuts are loosened using the stud tensioners.

9. Reactor vessel head studs and nuts are removed and stored.

10. Guide studs are installed in three stud holes. The remaining stud holes are plugged.

11. The vessel head lifting grid tripod is installed while final preparations are made for underwater lights, tools, and fuel transfer system. The blind flange of the tube enclosing the fuel transfer tube is removed.

12. The reactor vessel head is unseated and raised by the plant crane.

13. The reactor cavity is filled with borated water to the vessel flange.

14. The head is slowly lifted while water is pumped into the cavity. The water level and vessel head are raised simultaneously, keeping the water level just below the head.

15. The reactor vessel head is removed to a dry storage area.

16. Control rod drive shafts are unlatched using the drive shaft unlatching tool. The disconnection of the drive shafts from the rod cluster control is verified. The control rod drive shafts remain with the reactor vessel upper internals.

17. The reactor internals lifting rig is lowered into position over the guide studs by the plant crane. The rig is then secured to the support plate of the upper internals structure.

18. Reactor vessel upper internals and control rod cluster drive shafts are lifted out of the vessel and stored in the underwater storage stand in the refueling cavity.

19. Fuel assemblies and control rod clusters are now free from obstructions and are ready to be removed from the reactor core.

\section{B.3.1.3 Phase III - Fuel Handling}

1. The refueling sequence is started with the refueling machine.

2. The machine is positioned over a fuel assembly in the most depleted region of the core.

3. The fuel assembly is lifted to a predetermined height sufficient to clear the reactor vessel and still have sufficient water covering it to prevent any radiation hazard to the operating personnel. 
4. The refueling machine is moved to line up the fuel assembly with the fuel transfer carriage.

5. The fuel transfer carriage is moved into the fuel transfer canal from the fuel building. In one of the containers is a fresh fuel assembly; the second container is empty.

6. Fuel assembly containers are tipped upright by the hydraulically operated lifting arm.

7. The refueling machine loads the spent fuel assembly into the empty fuel assembly container of the carriage and then unloads the fresh fuel assembly and places it in the core.

8. Containers are lowered to the horizontal position by the lifting arm.

9. The carriage is moved through the fuel transfer tube to the fuel building.

10. Fuel assembly containers are tipped upright. A new assembly brought from its storage location is loaded into the empty fuel assembly container.

11. The spent fuel assembly is unloaded by the long-handled tool attached to the fuel handling machine hoist.

12. The fuel assembly container is lowered to the horizontal position and the conveyor car is moved back into the containment.

13. Meanwhile, the refueling machine has moved another spent fuel assembly with a rod cluster control assembly into the rod cluster control change fixture.

14. The refueling machine takes the fresh fuel assembly, which is to receive a rod cluster control, from the fuel transfer basket and places it in the rod cluster control change fixture.

15. The rod cluster control change fixture removes the rod cluster control assembly from the spent fuel.

16. The rod cluster control assembly is placed in the fresh fuel assembly.

17. The spent fuel assembly is removed from the rod cluster control change fixture and placed in one of the fuel assembly containers.

18. The fresh fuel assembly with rod cluster control assembly is taken by the refueling machine to the core.

19. Fuel assembly containers are lowered to the horizontal position by the lifting arm.

20. The carriage is moved through the fuel transfer tube to the fuel building to continue the fueling process.

21. Partially spent fuel assemblies are moved from one region to another region of the reactor core.

22. New fuel assemblies are loaded into the proper region of the core.

23. Applicable rod cluster control and thimble plug shuffling is done with the manipulator crane, rod cluster control change fixture, and thimble plug handling tool.

\section{B.3.1.4 Phase IV - Reactor Reassembly}

1. The fuel transfer tube gate valve is closed.

2. Old O-rings are removed from the reactor vessel head, the grooves are cleaned and new rings are installed. 
3. Reactor vessel upper internals are placed in the vessel by the polar crane. The reactor vessel internals lifting rig is removed and stored.

4. Control rod drive shafts are latched to the rod cluster control assemblies.

5. The reactor vessel head is picked up by the plant crane and positioned over the reactor vessel.

6. The reactor vessel head is slowly lowered. Simultaneously, the water level is kept just below the head.

7. When the head is about 1 foot above the vessel flange, the refueling cavity is completely drained, and the flange surface is cleaned.

8. The reactor vessel head is seated.

9. The reactor vessel head lifting rig tripod is removed and the cavity is decontaminated.

10. Stud hole plugs and guide studs are removed.

11. Head studs and nuts are installed and torqued.

12. The blind flange is installed to close the containment side of the fuel transfer tube.

13. The vessel head insulation and instrumentation are installed.

14. Missile shield support beams and cable trays are installed.

15. Control rod drive mechanisms are checked out for proper operation.

16. The control rod drive missile shield is installed.

17. Electrical leads and cooling air ducts are installed.

18. Incore instrumentation thimble guides are inserted into the core and sealed at the seal table.

19. The hydrostatic test is performed on the reactor vessel.

\section{B.3.1.5 Phase V Preoperational Checks, Tests, and Startup}

Preoperational physics tests are performed as necessary prior to restart of the reactor.

\section{B.3.2 Spent Fuel Transfer from the Spent Fuel Pool}

After a sufficient decay period, the spent fuel can be removed from the fuel racks and loaded into a shipping cask for removal from the site and shipment to an independent spent fuel storage facility or for storage in dry-storage canisters at the reactor site. These shipping casks are made of steel and lined with lead. The casks range in size from 25 tons to 100 tons. The smallest casks can be transported by truck, but the largest must be shipped by rail. The casks are lowered into the spent fuel pool and filled with spent fuel underwater. Once the cask has been filled with spent fuel, it is closed, removed from the spent fuel pool and drained. 


\section{B.4 IAEA Safeguards Approach}

The reference facility is an item facility from the point of view of the International Atomic Energy Agency (IAEA) safeguards, i.e., the special fissionable material at the facility is confined in identifiable fuel assemblies, the integrity of which normally remains unaltered during their residence at the facility. (Should the fuel assemblies be damaged so that individual fuel rods are present, they are safeguarded by identification and accounting for rods, portions of rods, or groups of rods, typically in fuel component containers, as described in the accountability discussion above.) The quantity of special fissionable material initially present in each fuel assembly is declared at the fuel fabrication plant. Because the fuel fabrication plant supplying fuel to the reference facility is under IAEA safeguards, the nuclear material in fuel assemblies shipped to the reference facility is quantitatively verified by the IAEA. For IAEA accountability purposes, this quantity is assumed to remain unchanged until the fuel assembly is discharged from the core. Plutonium production and fissile material depletion from burnup are calculated by the reactor operator from the irradiation history of each fuel assembly and the fissile material inventories of discharged (used) fuel assemblies are modified accordingly. The entire reference facility constitutes one material balance area (MBA). Hence, the loading of fresh fuel into the reactor core and the discharge of irradiated fuel from it to the on-site spent fuel storage do not constitute an inventory change. Nevertheless, information on these movements is essential for effective IAEA safeguards, and the reference facility operator maintains detailed operating records on these internal transfers.

The essential elements of safeguards are organized to provide an information system that permits the IAEA to monitor operational activities so that the validity of the operator's account of fuel operations can be verified. This is illustrated schematically in Figure B.6. The upper flow diagram represents the physical fuel handling, including the possibilities for diversion. The middle flow diagram represents the nuclear material accounting by the operator, concerning the activities that have occurred. If this declared record of storage status and transfers accurately reflects the real inventories and transfers, then there can be a high degree of confidence that diversion activity has not occurred.

The IAEA's safeguards activities, represented in the bottom flow path of Figure B.6, monitor the physical activity in the storage and material transfer areas of the reference facility for accountancy verification purposes. Any activity observed that does not correspond to that declared will initiate a preplanned process to reestablish confidence that the declared record reflects the real inventory. That process might lead to an examination and validation of the entire inventory, an expensive task which should be avoided. 


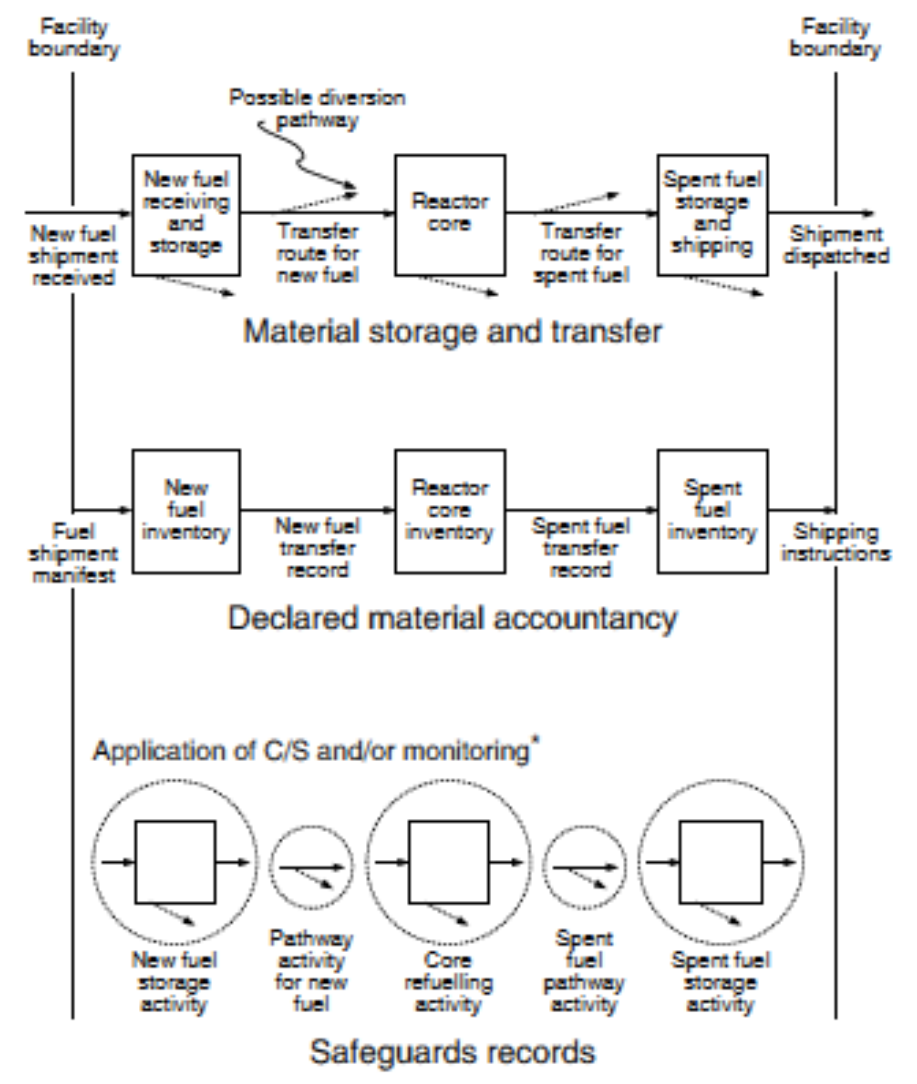

Figure B.6. Essential Elements of IAEA Safeguards

At the reference facility intermittent surveillance is used, at a frequency determined from the estimated operating time required to accomplish a diversion. At the reference facility, refueling operations occur only about once every 18 months with new fuel delivered only near the beginning of the operation. Therefore, fuel storage areas can be placed under surveillance and/or sealed for long periods. The integrity of the area boundaries, seals on access points and evaluation of surveillance records provide evidence of no activity for declared operations in that area. Optical surveillance cameras monitoring a work area may capture a frame once per minute or slower if a safeguards relevant activity would take, for example, 10 minutes. Motion sensors may are also used to trigger the cameras covering the fuel transfer canal and spent fuel storage pool in the fuel building.

Accidental or inadvertent loss of surveillance has to be interpreted as a potential safeguards concern and would trigger a process which may lead to reverification. Since reverification is disruptive and costly, additional safeguards provisions including redundant surveillance and the subdivision of sealed enclosures are employed to avoid surveillance loss and to significantly simplify the reverification process.

For reference plant fuel, the significant quantities of low enriched uranium (75 kg of uranium-235), would be contained in approximately five fuel assemblies with 3.1 percent enriched uranium, six fuel assemblies with 2.6 percent enriched uranium, and seven fuel assembles of 2.1 percent enriched uranium. The $8 \mathrm{~kg}$ significant quantity of plutonium is contained in approximately two irradiated fuel assemblies. 


\section{B.4.1 IAEA Safeguards Measures}

The IAEA employs three types of safeguards measures to verify that diversion and unauthorized nuclear material production have not taken place at the reference facility:

1. Design examination/verification to structure the remaining safeguards measures in a manner that will be effective

2. Nuclear material accountancy to ensure that all nuclear material is in declared locations being used for declared activities

3. Containment surveillance to preserve the integrity of verified accountancy data; provide information on the movements, or possible movements, of nuclear material; and ensure that the fuel movement counts at key measurement points (KMPs) are complete.

\section{B.4.1.1 Design Examination/Verification}

Design examination/verification is based upon review of the design of essential equipment as the facility is begin designed and constructed and ensures that the physical configuration of this essential equipment in the facility conforms to the reviewed design. Subsequent inspections verify that the physical configuration of the essential equipment has not been modified in a manner that departs so significantly from the reviewed design that it creates the potential for diversion of nuclear material or facility misuse. The following reference facility equipment has been declared as essential equipment:

- reactor pressure vessel

- new fuel assemblies

- control rods

- primary coolant

- primary coolant pumps

- steam generators

- primary coolant system pressurizer

- spent fuel shipping/storage casks

- chemical and volume control system

- in-core, ex-core, and reactor coolant system instrumentation

- turbine generator set, including condenser and steam jet air ejectors

- component cooling water system

- service water system

- circulating water system. 


\section{B.4.1.2 Nuclear Material Accountancy}

For this application of FSA, the facility is considered as a single MBA with a number of well-defined key measurement points (KMPs), through which material is transferred-physically or as accountancy transactions - or where it is stored or used. Accountancy is carried out on an item basis, using the fuel assembly identification number for intact fuel assemblies. The nuclear material content of each assembly is based on the verified manufacturer's measurements and on the reactor operating data. The operator keeps accountancy records of the inventory of nuclear material at each location, of the transfers into and out of the facility and of transfers between locations within the facility. Reports on inventories and external transfers are made periodically to the IAEA. Verification by the IAEA of the correctness of the records and reports is carried out by record audit, item counting, item identification, and non-destructive assay (NDA) examination.

An important part of the safeguards approach is that at annual intervals the operator is required to carry out a physical inventory taking (PIT) of all the nuclear material at the facility and provide a declaration in a Physical Inventory Listing (PIL) to the IAEA. The results of the operator's inventory are verified by the IAEA at the physical inventory verification (PIV).

\section{B.4.1.3 Containment/Surveillance}

For IAEA safeguards purposes, the containment used in a containment/surveillance (C/S) system consists of structural features of a nuclear facility or of equipment that permit the IAEA to establish the physical integrity of an area or item by preventing undetected access to, or movement of, nuclear or other material, or interference with the item, IAEA safeguards equipment, or data. Containment areas in the representative facility include:

- the walls of the spent fuel storage pool

- spent fuel shipping casks and storage containers

- reactor containment

- the walls of the fuel transfer canal.

The continued integrity of the containment is ensured by containment examination, and by $\mathrm{C} / \mathrm{S}$ measures for penetrations of the containment such as doors, vessel lids, and water surfaces. Similarly, surveillance is the collection of information through inspector and/or instrumental observation, which is aimed at monitoring the movement (or non-movement) of nuclear material, detecting interference with the containment, or tampering with IAEA safeguards devices, samples, or data. There is a range of surveillance devices available, and the use of any particular one depends on the individual circumstances.

The instruments used to measure declared movements of nuclear material or detect undeclared movements can be interrogated at intervals at the site by visiting inspectors. However, these instruments also automatically transmit (authenticated and encrypted) data from the reference facility to IAEA Headquarters. Like all C/S and NDA systems used for safeguards purposes, the design of these systems takes into account the possibility of intentional actions by a potential diverter to defeat the system and thereby conceal the undeclared removal of material. Thus, the equipment is tamper-resistant or tamperindicating and incorporates validation measures for stored and transmitted data. The optical surveillance systems employ special tamper-resistant transmission lines. The radiation monitoring and NDA systems 
are designed to resist tampering using radiation sources. To minimize this potential vulnerability, detectors are placed as close as possible to the item being verified (providing a strong and unique signal) and having the detector within the field of view of optical surveillance systems. Where practicable, designs employ monitoring of radiation background (or a watchdog source in areas where the background is low) to detect intentional interruption of the signal or data transmission chain.

The layout of the containment surveillance equipment at the reference facility is shown in Figure B.7. The design of the $\mathrm{C} / \mathrm{S}$ measures applied to core and spent fuel employs at least $\mathrm{C} / \mathrm{S}$ components complementary to each other in two areas (i.e., pool surveillance in the fuel storage building and hatch $\mathrm{seal} /$ surveillance in the reactor containment). As shown, the C/S measures include applying seals and/or optical surveillance to ensure that there is no undetected opening of the reactor vessel, and the use of optical surveillance to detect diversion from the spent fuel pool or from an open pressure vessel. The design of the reference facility permits the top of the entire core to be viewed when the pressure vessel head and any internals normally above the core are removed. By flooding the region above the core with clear water and connecting it with the spent fuel pool, fuel can be moved while being cooled and shielded by the water. This water shielding is transparent to visible light, permitting direct observation of refueling activities by optical instruments and inspectors. The water is also transparent to ultraviolet light, permitting the use of Cerenkov glow from irradiated fuel to verify the irradiated fuel contents in the spent fuel pool and in the core. The safeguards approach takes advantage of this water clarity and visibility.

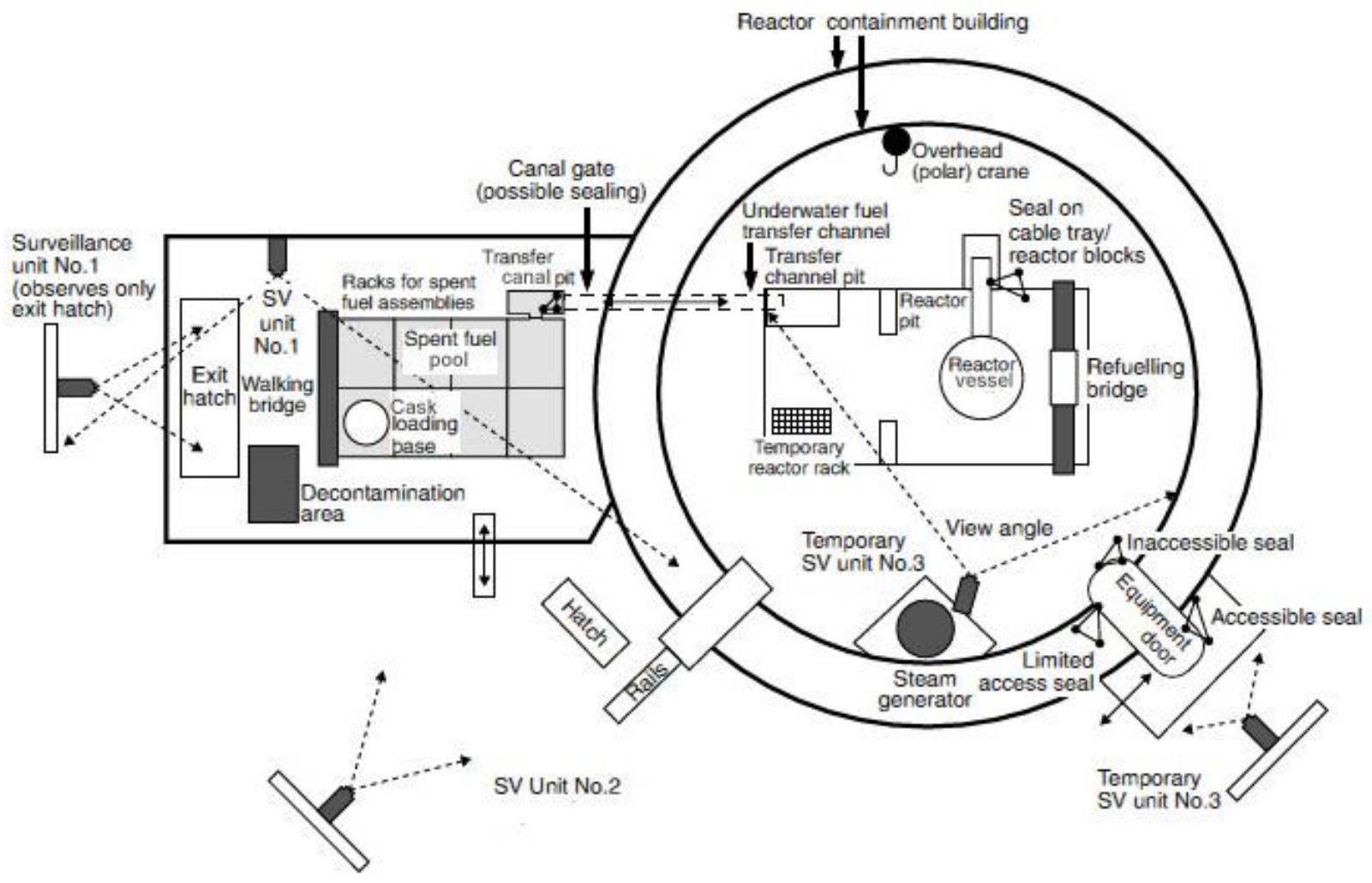

Figure B.7. Containment/Surveillance Design 


\section{B.4.2 Safeguards Activities}

\section{B.4.2.1 Fresh Fuel Verification}

Fresh fuel assemblies received at the reactor site are considered to be identifiable items and all subsequent inspection activities are concerned with the verification of item identity and integrity (i.e., whole assemblies remaining as such). This verification ensures that the nuclear material stated to be present is in fact there. The assemblies present are counted and their identification numbers noted. Additionally, or as an alternative to identification, the IAEA may also carry out NDA measurements as a sampling basis to confirm the fresh fuel receipt declaration or to detect if there are any discrepancies in the nuclear material content. The NDA techniques used are based upon low resolution gamma ray spectroscopy using a portable multichannel analyzer and either a $\mathrm{NaI}$ scintillation counter or a CdTe solid-state detector. Both systems are designed to measure enrichment. For reasons of economy, the plant operator arranges to receive fresh fuel as close as possible to the scheduled refueling shutdown. To complete the necessary verification measures, the IAEA typically schedules an inspection at a time, just prior to refueling, when all the fresh fuel has been received but before it has been transferred to underwater storage.

\section{B.4.2.2 Verification of Fuel Assemblies in the Reactor Core}

The seals on sealed reactor vessels are verified at the annual PIV and also at three-month intervals. Direct verification of the fuel in the core is timed to coincide with the operator's checks to ensure that the refueling of the core has taken place as declared. Alternatively, if the entire core has been discharged to the spent fuel pool, the core fuel is verified as part of the spent fuel inventory. Verification involves counting the number of assemblies in the core, and in practice also the verification of the serial numbers of all of the assemblies using the operator's underwater television system. This approach is justified by the fact that the reactor area is maintained under surveillance from the time that the reactor vessel containment seal is detached and the assumption that, provided no spent fuel transport container movements have been detected, the spent fuel was transferred from the core to the spent fuel pool and has been replaced by fresh fuel. Furthermore, it is usually possible to distinguish between fresh fuel assemblies newly loaded into the core and irradiated assemblies remaining in the core from previous power cycles.

The only obvious weakness in this approach is that the verification knowledge of the reactor core following the PIV is maintained solely through an optical surveillance system, which may not be capable of detecting all transfers of fuel assemblies between the core and the spent fuel pool. Verification of the fuel in the spent fuel pool is carried out at the inspection at which the reactor vessel containment seals are attached. Sealing the reactor vessel containment is employed as a means of maintaining the verification knowledge of the core fuel gained during the inspection activities performed in connection with the PIV. The reactor vessel is also maintained under optical surveillance so that core-fuel verification knowledge is independently maintained by both seals and surveillance, i.e., under a dual C/S system.

\section{B.4.2.3 Spent Fuel Verification and C/S}

The spent fuel verification activities are applied in conjunction with the annual PIV and involve item counting of the whole population of spent fuel assemblies and NDA measurements to detect undeclared 
removal of the nuclear material. These measurements are based on observation of the Cerenkov glow using an optical intensifier.

In accordance with the principle contained in agreements based on INFCIRC/153 (IAEA 1972), whereby $\mathrm{C} / \mathrm{S}$ is an important complementary measure to nuclear material accountancy, the IAEA uses $\mathrm{C} / \mathrm{S}$ systems to maintain the knowledge gained from the NDA measurement of spent fuel. The modular integrated video system (MIVS), based upon closed-circuit television (CCTV), is used for this purpose at the reference facility.

As illustrated in Figure B.7 surveillance systems have been installed to survey spent fuel storage areas, spent fuel transfer routes and the reactor pressure vessel when it is open for refueling. During refueling, arrangements are made to ensure that no spent fuel shipments occur. The principal objective of the surveillance is to detect the presence of spent fuel shipping casks or other objects capable of containing irradiated nuclear material. The assumption is made that if a shipping cask or similar object is seen to leave the area covered by the surveillance, then a change in the inventory of the spent fuel may have occurred. To ensure that a complete optical surveillance record is obtained, it is vital that adequate lighting be maintained at all times. In order to be able to interpret the optical or other surveillance record, the IAEA relies on the operator to maintain detailed records of operations involving shipping casks or cask-like objects in the surveillance zone, and to make these records available to the IAEA inspector either for transcription or as retainable copy. Subsequently, the surveillance record is compared with the operator's information. The chronology of events is compared with the declared inventory changes to determine whether the surveillance record may be accepted as providing conclusive confirmation of the operator's/state's declaration.

Traditionally, the IAEA has applied a simple interpretation to data obtained from surveillance reviews, in that it accepted that an object that could be confidently recognized to be a shipping cask of the type described in the design information could be taken to contain no more than its declared capacity of fuel assemblies. However, the increasing use of reconstitutable assemblies introduces a significant uncertainty, in that assembly dismantling could permit a change in the packing fraction of the container. As a consequence, the detection of a transport container or similar object leads to the conclusion that the knowledge of spent fuel has been compromised and reverification is necessary. Provided that the surveillance system has otherwise provided conclusive results, reverification of the spent fuel inventory would be undertaken in conjunction with the PIV and would, under normal circumstances, be based upon the use of equipment to measure Cherenkov radiation.

\section{B.4.2.4 Detection of the Unrecorded Production of Direct-use Material}

This capability depends largely on the ability of the inspector to examine in detail the spent fuel storage pool, either at the time of the operator's verification of core loading (called core control in safeguards terminology) or, equally effectively, at the time of the verification of the spent fuel assemblies conducted when the reactor vessel containment seal is attached. To be able to ensure that no undeclared irradiation (for plutonium production) has taken place, it is essential that either the reactor vessel is closed and under $\mathrm{C} / \mathrm{S}$, or that, during the period when the core is accessible, it is verified that material is exchanged only between the core and the spent fuel pool. 


\section{B.5 Reference}

IAEA - International Atomic Energy Agency. 1972. The Structure and Content of Agreements Between the Agency and States Required in Connection with the Treaty on the Non-Proliferation of Nuclear Weapons. INFCIRC/153 (Corrected), International Atomic Energy Agency, Vienna, Austria. 


\section{Appendix C}

Completed Facility Safeguardability Assessment Screening Tool 



\section{Appendix C}

\section{Completed Facility Safeguardability Assessment Screening Tool}

\begin{tabular}{|c|c|c|}
\hline \multicolumn{3}{|c|}{ Facility Safeguardability Assessment Screening Tool } \\
\hline Question & Response & Reasoning \\
\hline $\begin{array}{l}\text { 1. Does this design differ from the } \\
\text { comparison design/process in ways that } \\
\text { have the potential to create additional } \\
\text { diversion paths or alter existing diversion } \\
\text { paths? }\end{array}$ & Yes / No & $\begin{array}{l}\text { Potential for new diversion paths associated with consolidation of } \\
\text { refueling areas for multiple modules. More detailed diversion path } \\
\text { analysis is required to assess the significance of this potential path. } \\
\text { See answers to subsidiary questions. }\end{array}$ \\
\hline $\begin{array}{l}\text { 1.1. Does this design introduce nuclear } \\
\text { material of a type, category, or form } \\
\text { that may have a different significant } \\
\text { quantity or detection time objective } \\
\text { than previous designs/processes (e.g., } \\
\text { mixed oxide rather than low enriched } \\
\text { uranium, irradiated vs. unirradiated or } \\
\text { bulk rather than items)? }\end{array}$ & Yes / No & \\
\hline $\begin{array}{l}\text { 1.2. Does this design layout eliminate or } \\
\text { modify physical barriers that would } \\
\text { prevent the removal of nuclear } \\
\text { material from process or material } \\
\text { balance areas, e.g., circumventing a } \\
\text { key measurement point (KMP)? }\end{array}$ & Yes / No & $\begin{array}{l}\text { The NuScale design common refueling area for multiple modules } \\
\text { reduces the safeguards effectiveness or renders infeasible the locking } \\
\text { and sealing of the fuel transfer tube when modules are in operation. } \\
\text { This makes it more difficult to maintain continuity of knowledge of the } \\
\text { inventory of the reactor vessels and the spent fuel pool. It may be } \\
\text { possible to compensate by locking and sealing the removable pool lids } \\
\text { and other monitoring approaches. However, it is not likely to be } \\
\text { possible to have an inspector present every time these seals need to be } \\
\text { broken and available to affix new seals after the module is refueled. } \\
\text { Perhaps remote surveillance could be employed to compensate. }\end{array}$ \\
\hline
\end{tabular}




\begin{tabular}{|c|c|c|}
\hline \multicolumn{3}{|c|}{ Facility Safeguardability Assessment Screening Tool } \\
\hline Question & Response & Reasoning \\
\hline $\begin{array}{l}\text { 1.3. Does this design obscure process areas } \\
\text { or material balance area (MBA) } \\
\text { boundaries making } \\
\text { containment/surveillance or } \\
\text { installation of verification } \\
\text { measurement and monitoring } \\
\text { equipment more difficult? }\end{array}$ & Yes / No & $\begin{array}{l}\text { The need to transport NuScale reactor vessels to a common refueling } \\
\text { area necessitates the monitoring of a significantly larger area. Thus } \\
\text { installation of containment/surveillance or monitoring equipment will } \\
\text { be more difficult and expensive. }\end{array}$ \\
\hline $\begin{array}{l}\text { 1.4. Does this design introduce materials } \\
\text { that could be effectively substituted } \\
\text { for safeguarded nuclear material to } \\
\text { conceal diversion? }\end{array}$ & Yes / No & Fuel material is similar, only differing in dimension, with PWR fuel. \\
\hline $\begin{array}{l}\text { 2. Does this design differ from the } \\
\text { comparison design in a way that increases } \\
\text { the difficulty of design information } \\
\text { examination (DIE) and verification (DIV) } \\
\text { by IAEA inspectors? }\end{array}$ & Yes / No & See response to question 2.4 . \\
\hline $\begin{array}{l}\text { 2.1. Does the design incorporate new or } \\
\text { modified technology? If so, does the } \\
\text { IAEA have experience with the new or } \\
\text { modified technology? }\end{array}$ & Yes / No & $\begin{array}{l}\text { General technology is similar to conventional PWR technology. The } \\
\text { difference in refueling associated with the removal of components } \\
\text { additional to the PWR reactor head does not appear to make a } \\
\text { significant difference. }\end{array}$ \\
\hline $\begin{array}{l}\text { 2.2. Are there new design features with } \\
\text { commercial or security sensitivities } \\
\text { that would inhibit or preclude IAEA } \\
\text { inspector access to equipment or } \\
\text { information? }\end{array}$ & Yes / No & $\begin{array}{l}\text { There is insufficient information in the description of the NuScale to } \\
\text { answer this question. Need to know whether anything that could be } \\
\text { seen with visual access to the NuScale removal pool, spent fuel storage } \\
\text { area, and the unit transfer system is proprietary. These locations and } \\
\text { activities within them would need to be monitored to retain Continuity } \\
\text { of Knowledge (CoK). }\end{array}$ \\
\hline
\end{tabular}




\begin{tabular}{|c|c|c|}
\hline \multicolumn{3}{|c|}{ Facility Safeguardability Assessment Screening Tool } \\
\hline Question & Response & Reasoning \\
\hline $\begin{array}{l}\text { 2.3. Do aspects of the design limit or } \\
\text { preclude inspector access to, or the } \\
\text { continuous availability of, Essential } \\
\text { Equipment for verification or testing? }\end{array}$ & Yes / No & There does not appear to be a significant difference in this area. \\
\hline $\begin{array}{l}\text { 2.4. Are there aspects of the design that } \\
\text { would preclude or limit IAEA } \\
\text { maintenance of Continuity of } \\
\text { Knowledge (CoK) associated with } \\
\text { design verification during the life of } \\
\text { the facility? }\end{array}$ & Yes / No & $\begin{array}{l}\text { The NuScale design common refueling area for multiple modules and } \\
\text { relatively frequent module refuelings (perhaps } 6 \text { per year) makes it } \\
\text { more difficult to maintain CoK. (See notes in rationale for questions } \\
1.2 \& 2.2 \text { for discussion of challenges of maintaining CoK of reactor } \\
\text { core loading.) }\end{array}$ \\
\hline $\begin{array}{l}\text { 3. Does this design/process differ from the } \\
\text { comparison design/process in a way that } \\
\text { makes it more difficult to verify that } \\
\text { diversion has not taken place? }\end{array}$ & Yes / No & See answers to subsidiary questions. \\
\hline
\end{tabular}




\begin{tabular}{|c|c|c|}
\hline \multicolumn{3}{|c|}{ Facility Safeguardability Assessment Screening Tool } \\
\hline Question & Response & Reasoning \\
\hline $\begin{array}{l}\text { 3.1.1. Does the plant/process design } \\
\text { evaluated reduce the measurement } \\
\text { accuracy or otherwise impede the } \\
\text { use of Inventory Key } \\
\text { Measurement Points (IKMP). If } \\
\text { so, are there other well defined } \\
\text { locations that could be considered } \\
\text { by the IAEA as IKMPs. }\end{array}$ & Yes / No & $\begin{array}{l}\text { The double stacking of NuScale fuel assemblies in the fuel storage } \\
\text { pool also impedes PIV because the upper level assemblies must be } \\
\text { moved to gain visual and NDA access to the fuel assemblies on the } \\
\text { lower level. The inability to schedule PIV when the reactor core } \\
\text { assemblies are visually accessible for all reactor units impedes the } \\
\text { ability to select an IKMP where all in-core fuel assemblies are visually } \\
\text { accessible. }\end{array}$ \\
\hline $\begin{array}{l}\text { 3.1.2. Does the plant/process design } \\
\text { evaluated impede or preclude the } \\
\text { collection/storage of inventory at } \\
\text { IKMPs at the time of PIT/PIV? }\end{array}$ & Yes / No & See rationale for question 3.1.1. \\
\hline $\begin{array}{l}\text { 3.1.3. Does the design preclude } \\
\text { PIT/PIV measurements on some } \\
\text { inventory? If so, does the new } \\
\text { design include features to permit } \\
\text { CoK to be maintained from a } \\
\text { previous measurement and } \\
\text { verification? }\end{array}$ & Yes / No & $\begin{array}{l}\text { Refueling of multiple modules makes a physical inventory more } \\
\text { difficult because there is no time in normal operation when all fuel } \\
\text { assemblies are visually accessible. Thus the complete physical } \\
\text { inventory cannot be } 100 \% \text { verified by visual inspection/NDA. }\end{array}$ \\
\hline $\begin{array}{l}\text { 3.1.4. Does the design/process employ } \\
\text { nuclear material types, categories, } \\
\text { or forms that are more difficult to } \\
\text { measure accurately at IKMP? If } \\
\text { so, can the plant accountancy } \\
\text { measurement systems meet } \\
\text { International Target Values (ITV) } \\
\text { for the PIT? }\end{array}$ & Yes / No & $\begin{array}{l}\text { No significant difference. Both NuScale and PWR designs permit item } \\
\text { accountability. Smaller fuel pins in the NuScale assemblies make } \\
\text { accounting for damaged NuScale fuel pins less significant/ more } \\
\text { accurate than for PWR. (SFM inventory in damaged fuel pins is } \\
\text { usually booked as an estimate based upon the physical configuration of } \\
\text { the damaged fuel pin.) }\end{array}$ \\
\hline
\end{tabular}




\begin{tabular}{|c|c|c|}
\hline \multicolumn{3}{|c|}{ Facility Safeguardability Assessment Screening Tool } \\
\hline Question & Response & Reasoning \\
\hline $\begin{array}{l}\text { 3.1.5. Does the design preclude or } \\
\text { limit the ability of the IAEA to } \\
\text { take/analyze independent samples } \\
\text { for the PIV? }\end{array}$ & Yes / No & $\begin{array}{l}\text { The double stacking of NuScale fuel assemblies in the fuel storage } \\
\text { pool also impedes PIT and PIV because the upper level assemblies } \\
\text { must be moved to gain visual and NDA access to the fuel assemblies } \\
\text { on the lower level. }\end{array}$ \\
\hline $\begin{array}{l}\text { 3.1.6. Does the process design } \\
\text { preclude controls to prevent } \\
\text { inventory change or movement } \\
\text { between the time of the PIT and } \\
\text { the PIV? If so, does the design } \\
\text { include measures to maintain } \\
\text { CoK of the changed or moved } \\
\text { inventory between the time of the } \\
\text { PIT and the PIV? }\end{array}$ & Yes / No & $\begin{array}{l}\text { Depending upon the lag time between the PIT and PIV, it is possible } \\
\text { that a unit could reach the refueling point between the PIT and PIV. } \\
\text { There are no design measure described that would maintain CoK under } \\
\text { this circumstance. Perhaps remote monitoring of refueling operations } \\
\text { could maintain CoK. }\end{array}$ \\
\hline $\begin{array}{l}\text { 3.2. Does this design impair the ability of } \\
\text { the operator to produce timely and } \\
\text { accurate interim inventory } \\
\text { declarations or for the IAEA to } \\
\text { perform timely and accurate Interim } \\
\text { Inventory Verification (IIV)? }\end{array}$ & Yes / No & $\begin{array}{l}\text { Like the PWR, the NuScale design can employ item accountability so } \\
\text { interim inventory declarations should not be an issue. }\end{array}$ \\
\hline $\begin{array}{l}\text { 3.2.1 Does design impede or preclude } \\
\text { shutdown of the process for an } \\
\text { IIV? }\end{array}$ & Yes / No & $\begin{array}{l}\text { Differing refueling schedules make it infeasible to conduct an IIV for } \\
\text { all fuel assemblies in reactor unit cores. }\end{array}$ \\
\hline $\begin{array}{l}\text { 3.2.2 Does the design impede or } \\
\text { preclude the collection/storage of } \\
\text { inventories at IKMP, which } \\
\text { provide access for measurement } \\
\text { and declaration by the operator } \\
\text { and verification by the IAEA, at } \\
\text { the interim inventory cut-off time } \\
\text { (CoT)? }\end{array}$ & Yes / No & $\begin{array}{l}\text { Differing refueling schedules make it infeasible to conduct a physical } \\
\text { inventory for all fuel assemblies in reactor unit cores during one IIT. }\end{array}$ \\
\hline
\end{tabular}




\begin{tabular}{|c|c|c|}
\hline \multicolumn{3}{|c|}{ Facility Safeguardability Assessment Screening Tool } \\
\hline Question & Response & Reasoning \\
\hline $\begin{array}{l}\text { 3.2.3 Does design create the potential } \\
\text { for Un-Measureable Inventory } \\
\text { (UMI) at the time of an IIV in } \\
\text { locations such as pipes, pumps, or } \\
\text { evaporators? If so, can the UMI } \\
\text { be accurately estimated by the } \\
\text { operator and can the estimation } \\
\text { method be verified by the IAEA? }\end{array}$ & Yes / No & $\begin{array}{l}\text { Because there is no possible physical inventory of the assemblies in the } \\
\text { reactor cores of units that are not shutdown at the time of the IIT, there } \\
\text { is the likelihood of items that cannot be physically verified or NDA } \\
\text { verified for SFM content (i.e., "measured"). }\end{array}$ \\
\hline $\begin{array}{l}\text { 3.2.4 Does the new plant/process } \\
\text { design increase the time required } \\
\text { for the operator to provide the } \\
\text { IAEA with an Interim Inventory } \\
\text { List (IIL) after the CoT }\end{array}$ & Yes / No & $\begin{array}{l}\text { No significant difference because both the NuScale and PWR designs } \\
\text { permit item accountability. }\end{array}$ \\
\hline $\begin{array}{l}\text { 3.2.5 Does design increase the expected } \\
\text { overall measurement uncertainty } \\
\text { of the operator's interim } \\
\text { inventory declaration? }\end{array}$ & Yes / No & $\begin{array}{l}\text { No significant difference because both the NuScale and PWR designs } \\
\text { permit item accountability. }\end{array}$ \\
\hline $\begin{array}{l}\text { 3.2.6 If the comparison facility } \\
\text { Safeguards Approach included } \\
\text { short-notice or no-notice interim } \\
\text { inspections, does the design } \\
\text { include real time measurement } \\
\text { and accounting systems that allow } \\
\text { for almost immediate inventory } \\
\text { declarations required to support } \\
\text { such inspections? }\end{array}$ & Yes / No & $\begin{array}{l}\text { The SDC development will consider the possibility of incorporating } \\
\text { short-notice or no-notice interim inspections. }\end{array}$ \\
\hline
\end{tabular}




\begin{tabular}{|c|c|c|}
\hline \multicolumn{3}{|c|}{ Facility Safeguardability Assessment Screening Tool } \\
\hline Question & Response & Reasoning \\
\hline $\begin{array}{l}\text { 3.3. Does this design impede timely and } \\
\text { accurate inventory change (IC) } \\
\text { measurements and declarations by the } \\
\text { operator and verification by the } \\
\text { IAEA? }\end{array}$ & Yes / No & $\begin{array}{l}\text { Like PWRs, the NuScale design can employ item accountability so } \\
\text { interim inventory change measurements and declarations should not be } \\
\text { an issue. Using the single MBA approach, the receipt and shipment } \\
\text { item counts and verification, including NDA, should be similar for } \\
\text { both designs. }\end{array}$ \\
\hline $\begin{array}{l}\text { 3.3.1. Does this design reduce the } \\
\text { accuracy of or otherwise impede } \\
\text { the use of customary Flow Key } \\
\text { Measurement Points (FKMPs). If } \\
\text { so, are there other well defined } \\
\text { locations that could be considered } \\
\text { by the IAEA as FKMP? }\end{array}$ & Yes / No & $\begin{array}{l}\text { No significant difference because both the NuScale and PWR designs } \\
\text { permit item accountability. }\end{array}$ \\
\hline $\begin{array}{l}\text { 3.3.2. Does the design increase the } \\
\text { measurement uncertainties at } \\
\text { FKMPs? If so, can the plant } \\
\text { accountancy system meet } \\
\text { International Target Values (ITV) } \\
\text { for inventory change }\end{array}$ & Yes / No & $\begin{array}{l}\text { No significant difference because both the NuScale and PWR designs } \\
\text { permit item accountability. Smaller fuel pins in the NuScale } \\
\text { assemblies make accounting for damaged NuScale fuel pins less } \\
\text { significant/more accurate. (See discussion in the rationale for item } \\
\text { 3.1.4.) }\end{array}$ \\
\hline $\begin{array}{l}\text { 3.3.3. Does the new design impede or } \\
\text { preclude IAEA verification of the } \\
\text { IC declarations by sample taking, } \\
\text { portable or installed } \\
\text { measurements systems, or by } \\
\text { joint-use of authenticated operator } \\
\text { systems? }\end{array}$ & Yes / No & $\begin{array}{l}\text { No significant difference because both the NuScale and PWR designs } \\
\text { permit item accountability. }\end{array}$ \\
\hline $\begin{array}{l}\text { 3.3.4. Does the design impede or } \\
\text { preclude IAEA verification of } \\
\text { calculated IC declarations such as } \\
\text { nuclear material loss and gain? }\end{array}$ & Yes / No & $\begin{array}{l}\text { No significant difference because both the NuScale and PWR designs } \\
\text { permit item accountability. The calculations of special fissionable } \\
\text { material changes due to reactor "burnup" are subject to commensurate } \\
\text { uncertainties. }\end{array}$ \\
\hline
\end{tabular}




\begin{tabular}{|c|c|c|}
\hline \multicolumn{3}{|c|}{ Facility Safeguardability Assessment Screening Tool } \\
\hline Question & Response & Reasoning \\
\hline $\begin{array}{l}\text { 3.3.5. Does the design impede or } \\
\text { preclude IAEA verification of IC } \\
\text { declarations that are determined } \\
\text { indirectly or based on historical } \\
\text { measurement data (e.g., waste } \\
\text { transfers to retained waste or } \\
\text { measured discards), decrease the } \\
\text { accuracy of the determinations, or } \\
\text { limit the availability of the } \\
\text { historical data }\end{array}$ & Yes / No & $\begin{array}{l}\text { No significant difference because both the NuScale and PWR designs } \\
\text { permit item accountability. Smaller fuel pins in the NuScale } \\
\text { assemblies make accounting for damaged NuScale fuel pins less } \\
\text { significant/more accurate so that damaged assembly/pin inventories } \\
\text { have lower uncertainty. (See discussion in the rationale for item } \\
\text { 3.1.4.) }\end{array}$ \\
\hline $\begin{array}{l}\text { 3.3.6. Does the design increase the time } \\
\text { required for the operator to } \\
\text { measure, calculate, prepare, and } \\
\text { approve the IC declarations? }\end{array}$ & Yes / No & $\begin{array}{l}\text { No significant difference because both the NuScale and PWR designs } \\
\text { permit item accountability. }\end{array}$ \\
\hline $\begin{array}{l}\text { 3.3.7. Does the new design increase the } \\
\text { expected overall measurement } \\
\text { uncertainty of the operator's IC } \\
\text { declaration? }\end{array}$ & Yes / No & $\begin{array}{l}\text { No significant difference because both the NuScale and PWR designs } \\
\text { permit item accountability. Smaller fuel pins in the NuScale } \\
\text { assemblies make accounting for damaged NuScale fuel pins less } \\
\text { significant/more accurate so that damaged assembly/pin inventories } \\
\text { have lower uncertainty. (See discussion in the rationale for item } \\
\text { 3.1.4.) }\end{array}$ \\
\hline $\begin{array}{l}\text { 3.4. Does this design impede the } \\
\text { introduction of or reduce the } \\
\text { usefulness of Other Strategic Points } \\
\text { (OSP) within a Material Balance Area } \\
\text { (MBA)? }\end{array}$ & Yes / No & $\begin{array}{l}\text { The use of an OSP in the fuel transfer canal to maintain an inventory } \\
\text { of fuel assemblies in the reactor vessel for the PWR does not translate } \\
\text { simply to the NuScale design. However, the designation of OSP in the } \\
\text { NuScale removal pool, the unit transfer canal, and the spent fuel } \\
\text { storage area will probably be part of the safeguards design concept for } \\
\text { NuScale. (See the answers to the subsidiary questions.) }\end{array}$ \\
\hline
\end{tabular}




\begin{tabular}{|c|c|c|}
\hline \multicolumn{3}{|c|}{ Facility Safeguardability Assessment Screening Tool } \\
\hline Question & Response & Reasoning \\
\hline $\begin{array}{l}\text { 3.4.1. Would OSP be less effective in } \\
\text { providing CoK of } \\
\text { measured/verified nuclear } \\
\text { material (e.g., reduce the } \\
\text { effectiveness of surveillance } \\
\text { systems or containment devices; } \\
\text { make installation of these systems } \\
\text { / devices more difficult; impede } \\
\text { or preclude access to or } \\
\text { maintenance of these systems/ } \\
\text { devices; make interfaces [e.g., } \\
\text { utility support or data } \\
\text { transmission] more difficult)? }\end{array}$ & Yes / No & $\begin{array}{l}\text { The required collection of OSP for NuScale would be more complex } \\
\text { than the simple PWR configuration. As a result the use of OSP would } \\
\text { be more difficult; but certainly still possible. }\end{array}$ \\
\hline $\begin{array}{l}\text { 3.4.2. Would OSP be less effective in } \\
\text { providing additional assurance for } \\
\text { high uncertainty verifications } \\
\text { done at KMPs (e.g., reduce } \\
\text { opportunities for random short- } \\
\text { notice sampling by IAEA } \\
\text { inspectors; reduce or eliminate } \\
\text { opportunities for correlation with } \\
\text { measurement data at related } \\
\text { locations, reduce the scope or } \\
\text { accuracy of Process Monitoring; } \\
\text { or limit or preclude IAEA ability } \\
\text { to authenticate plant PM systems } \\
\text { or introduce independent } \\
\text { systems)? }\end{array}$ & Yes / No & $\begin{array}{l}\text { No significant difference because both the NuScale and PWR designs } \\
\text { permit item accountability. With item accountability, there are no } \\
\text { KMPs that make high uncertainty verifications. }\end{array}$ \\
\hline
\end{tabular}




\begin{tabular}{|c|c|c|}
\hline \multicolumn{3}{|c|}{ Facility Safeguardability Assessment Screening Tool } \\
\hline Question & Response & Reasoning \\
\hline $\begin{array}{l}\text { 4. Does this design differ from the } \\
\text { comparison design in ways that create new } \\
\text { or alter existing opportunities for facility } \\
\text { misuse or make detection of misuse more } \\
\text { difficult? }\end{array}$ & Yes / No & $\begin{array}{l}\text { The presence of multiple units creates possible opportunities to } \\
\text { disguise misuse of one unit by swapping/duplicating operating records } \\
\text { with those from other units that were operated in accordance with } \\
\text { declared activities. (See answers to subsidiary questions.) }\end{array}$ \\
\hline $\begin{array}{l}\text { 4.1. Does this design differ from the } \\
\text { comparison facility/process by } \\
\text { including new equipment or process } \\
\text { steps that could change the nuclear } \\
\text { material being processed to a type, } \\
\text { category, or form with a lower } \\
\text { significant quantity or detection time } \\
\text { objectives? }\end{array}$ & Yes / No & $\begin{array}{l}\text { The production of plutonium by irradiation in the reactor core is } \\
\text { essentially the same in both designs. }\end{array}$ \\
\hline $\begin{array}{l}\text { 4.2. Should the comparison facility } \\
\text { safeguards approach employ agreed } \\
\text { upon short-notice visits or inspections, } \\
\text { measurements, or process parameter } \\
\text { confirmations, would this design } \\
\text { preclude the use of or reduce the } \\
\text { effectiveness of these measures? }\end{array}$ & Yes / No & $\begin{array}{l}\text { There are no differences in design that would adversely affect the } \\
\text { ability of IAEA inspectors to conduct effective Short-Notice or No- } \\
\text { Notice Random Inspections. }\end{array}$ \\
\hline $\begin{array}{l}\text { 4.3. Do the design and operating } \\
\text { procedures reduce the transparency of } \\
\text { plant operations (e.g., availability of } \\
\text { operating records and reports or } \\
\text { source data for inspector examination } \\
\text { or limited inspector access to plant } \\
\text { areas and equipment)? }\end{array}$ & Yes / No & $\begin{array}{l}\text { There may be opportunities to disguise unit misuse by swapping/ } \\
\text { duplicating operating records with those from other units that were } \\
\text { operated in accordance with declared activities. }\end{array}$ \\
\hline
\end{tabular}




\section{Appendix D}

Considerations in Deriving Functional Guidelines for the Application of International Safeguards 



\section{Appendix D}

\section{Considerations in Deriving Functional Guidelines for the Application of International Safeguards}

\section{D.1 Summary}

This section discusses considerations for the development of infrastructure functional guidelines to ensure safeguardability of the NuScale design. These considerations are based upon Design Measures to Facilitate Implementation of Safeguards at Future Water Cooled Nuclear Power Plants, International Atomic Energy Agency (IAEA) Technical Reports Series No. 392.

The table that follows discusses guidelines that should be employed in the derivation of explicit functional guidelines. The first column of the table presents general guidelines extracted verbatim from TRS 392. The second column expresses the guidance as infrastructure functional guideline(s), while the third column addresses applicability of the functional guideline(s) to the NuScale design. Where appropriate, this discussion references the aspects of the safeguards design concept (SDC) developed for the NuScale design. 
NuScale Safeguards Functional Guidelines

IAEA TRS 392 Guidance

NuScale Applicability /

Discussion of Guideline

Comments

\section{General Guidelines (Common to all future reactors)}

1. It would be useful for each plant to have its own safeguards center - a dedicated room for safeguards equipment and activities. (Sect. 6.9)
A dedicated space or room (IAEA Safeguards Room) should be provided for IAEA data processing, network, transmission, and other safeguards equipment on site. The room should provide privacy and work space for IAEA inspectors. The room should include provisions for meeting inspector health physics requirements (e.g., handling of dosimeters, protective clothing and respirators, showers). The room should also provide storage space for safeguards equipment. Provisions should be made for IAEA inspectors to control access to the room (e.g., locks and seals).

2. General approaches used to achieve high reliability in nuclear power plant design - redundancy, diversity and quality assurance - are also applicable to safeguards design. C/S may be used as partial or full backup for each other, and individual items of safeguards equipment such as surveillance cameras and seals may be duplicated for the same or closely similar functions to provide redundancy. (Sect. 7.1)
Services (e.g., cabling/ conduit, electrical power) provided to IAEA equipment mounting locations, recording device (blue cabinet) locations, the Safeguards Room, network hub location, and transmission equipment location should be designed with the same level of redundancy, diversity, quality assurance, and environmental qualification of plant safety equipment. Fabrication and installation of utilities/ equipment providing services to IAEA equipment mounting locations, recording device (blue cabinet) locations, safeguards lighting, the Safeguards Room, network hub location, and transmission equipment location should be performed to the same quality assurance and environmental qualification requirements as plant safety equipment. (Note however that the IAEA support equipment need not be designed/ qualified to operate in an accident environment.) Note: Diversity and redundancy of safeguards measures equipment employed to achieve safeguardability is an IAEA design responsibility. Quality of safeguards equipment is an IAEA procurement responsibility. Redundancy, diversity and quality of supporting infrastructure are a plant design guideline, which is reflected above.
General guideline directly applicable to NuScale.

General guideline directly applicable to NuScale.

Mounting space should be provided for IAEA General guideline directly 


\begin{tabular}{|c|c|c|c|}
\hline \multicolumn{4}{|c|}{ NuScale Safeguards Functional Guidelines } \\
\hline & IAEA TRS 392 Guidance & Discussion of Guideline & $\begin{array}{c}\text { NuScale Applicability / } \\
\text { Comments }\end{array}$ \\
\hline & $\begin{array}{l}\text { measures to minimize such } \\
\text { exposures and to provide } \\
\text { the necessary radiation } \\
\text { protection supplies and } \\
\text { services such as protective } \\
\text { clothing, dosimetry and } \\
\text { showers for IAEA } \\
\text { inspectors. (Sect. 7.1) }\end{array}$ & $\begin{array}{l}\text { equipment in areas with low ambient radiation } \\
\text { doses (ALARA). The space should be } \\
\text { accessible for inspection, monitoring, and } \\
\text { maintenance activities without interrupting } \\
\text { operations. }\end{array}$ & applicable to NuScale. \\
\hline & $\begin{array}{l}\text { The designers need to } \\
\text { examine those parts of the } \\
\text { plant through which } \\
\text { nuclear material moves for } \\
\text { possible diversion } \\
\text { pathways, and either } \\
\text { eliminate them or design to } \\
\text { accommodate the } \\
\text { installation of safeguards } \\
\text { measures such as seals, } \\
\text { surveillance equipment and } \\
\text { monitors, or combinations } \\
\text { thereof. (Sect. 7.1) }\end{array}$ & $\begin{array}{l}\text { This is not a specific design guideline. } \\
\text { Rather, it mandates a process like SBD to } \\
\text { identify safeguardability design guidelines. }\end{array}$ & $\begin{array}{l}\text { The results of this analysis are } \\
\text { embodied in the proposed } \\
\text { NuScale design functional } \\
\text { guidelines. }\end{array}$ \\
\hline & $\begin{array}{l}\text { Minimize the number of } \\
\text { access points in the reactor } \\
\text { containment and other } \\
\text { shielding structures } \\
\text { through which fuel } \\
\text { movement could take place } \\
\text { (Sect. 7.1) }\end{array}$ & $\begin{array}{l}\text { Openings in the containment structures that } \\
\text { are not intended to be used as nuclear material } \\
\text { (fuel) transfer routes should be designed so } \\
\text { that fuel assemblies cannot be moved through } \\
\text { them. If this cannot be accomplished, the } \\
\text { number of openings through which fuel } \\
\text { movement could take place should be reduced } \\
\text { to the minimum number consistent with plant } \\
\text { operations. }\end{array}$ & $\begin{array}{l}\text { Not directly applicable to } \\
\text { NuScale because containment is } \\
\text { integral to the NSS modules. } \\
\text { However, the guideline can be } \\
\text { generalized to the reactor hall } \\
\text { itself. }\end{array}$ \\
\hline & $\begin{array}{l}\text { Adequately illuminate the } \\
\text { containment access points, } \\
\text { the reactor vault and } \\
\text { fueling mechanism areas } \\
\text { (Sect. 7.1) }\end{array}$ & $\begin{array}{l}\text { Lighting frequency and intensity, including } \\
\text { underwater lighting, should meet minimum } \\
\text { specifications of selected C/S equipment for } \\
\text { lighting all areas subject to surveillance or } \\
\text { inspection. Sources of lighting within areas } \\
\text { subject to surveillance should be designed so } \\
\text { that they do not impede surveillance by } \\
\text { equipment or IAEA inspectors. Lighting } \\
\text { relied upon for safeguards purposes should be } \\
\text { supplied with electrical power from power } \\
\text { supplies, wiring, and switchgear meeting the } \\
\text { same reliability, quality, and labeling } \\
\text { requirements as the electrical power supplies } \\
\text { for other IAEA equipment (e.g., blue } \\
\text { cabinets). }\end{array}$ & $\begin{array}{l}\text { General guideline directly } \\
\text { applicable to NuScale. }\end{array}$ \\
\hline
\end{tabular}




\begin{tabular}{|c|c|c|}
\hline \multicolumn{3}{|c|}{ NuScale Safeguards Functional Guidelines } \\
\hline IAEA TRS 392 Guidance & Discussion of Guideline & $\begin{array}{c}\text { NuScale Applicability / } \\
\text { Comments }\end{array}$ \\
\hline $\begin{array}{l}\text { 7. Organize fuel transport } \\
\text { routes so that } \mathrm{C} / \mathrm{S} \text { systems } \\
\text { can be applied and } \\
\text { safeguards information can } \\
\text { be clearly interpreted, } \\
\text { particularly the ability to } \\
\text { distinguish between routine } \\
\text { and non-routine fuel } \\
\text { transfer and other activities } \\
\text { (Sect. 7.1) }\end{array}$ & $\begin{array}{l}\text { Should be incorporated in guidelines as } \\
\text { infrastructure guideline. }\end{array}$ & \\
\hline $\begin{array}{l}\text { 8. Minimize the effect of } \\
\text { safeguards on plant } \\
\text { operation by selecting } \\
\text { locations for safeguards } \\
\text { equipment that are } \\
\text { accessible for inspection, } \\
\text { monitoring and } \\
\text { maintenance and which do } \\
\text { not obstruct operations } \\
\text { (Sect. 7.1) }\end{array}$ & $\begin{array}{l}\text { Should be incorporated in guidelines as } \\
\text { infrastructure guideline. }\end{array}$ & \\
\hline $\begin{array}{l}\text { 9. Ensure that all safeguards } \\
\text { activities can be } \\
\text { accomplished safely and } \\
\text { expeditiously and that } \\
\text { safeguards equipment will } \\
\text { be reasonably protected } \\
\text { from unintentional damage } \\
\text { (Sect. 7.1) }\end{array}$ & $\begin{array}{l}\text { IAEA equipment should be protected from } \\
\text { unintentional damage by use of mounting } \\
\text { locations away from normal traffic areas, if } \\
\text { feasible, and by protective features (e.g., } \\
\text { enclosures) where the equipment cannot be } \\
\text { isolated. }\end{array}$ & $\begin{array}{l}\text { General guideline directly } \\
\text { applicable to NuScale. }\end{array}$ \\
\hline $\begin{array}{l}\text { 10. Clearly label all installed } \\
\text { equipment relevant to } \\
\text { safeguards (including } \\
\text { cabling, power supplies } \\
\text { and switches) to avoid } \\
\text { inadvertent interruptions in } \\
\text { surveillance and } \\
\text { monitoring (Sect. 7.1) }\end{array}$ & $\begin{array}{l}\text { Should be incorporated in guidelines as } \\
\text { infrastructure guideline. }\end{array}$ & \\
\hline $\begin{array}{l}\text { 11. Provide water purification } \\
\text { equipment to ensure water } \\
\text { clarity in the visible and } \\
\text { ultraviolet spectra (Sect. } \\
7.1 \text { ) }\end{array}$ & $\begin{array}{l}\text { Water chemistry/cleanup for cooling water in } \\
\text { the reactor vessel spent fuel storage area, and } \\
\text { spent fuel reconstitution area, should maintain } \\
\text { clarity such that surveillance by safeguards } \\
\text { measures, relying on the visible and } \\
\text { ultraviolet spectra, within and exterior to the } \\
\text { coolant, are not hindered. Water clarity in the } \\
\text { spent fuel storage area should be sufficient to }\end{array}$ & $\begin{array}{l}\text { Guideline is applicable to } \\
\text { NuScale but requires } \\
\text { modification to reflect the } \\
\text { differences between NuScale } \\
\text { refueling process and standard } \\
\text { LWR refueling process. }\end{array}$ \\
\hline
\end{tabular}




\begin{tabular}{llc}
\hline & NuScale Safeguards Functional Guidelines & \\
\hline IAEA TRS 392 Guidance & \multicolumn{1}{c}{ Discussion of Guideline } & $\begin{array}{c}\text { NuScale Applicability / } \\
\text { Comments }\end{array}$ \\
\hline & $\begin{array}{l}\text { permit operation of Cerenkov radiation } \\
\text { monitoring/ viewing instrumentation. Water } \\
\text { turbulence in areas covered by surveillance or } \\
\text { monitoring measures should be limited to } \\
\text { prevent distortions or reflections that would } \\
\text { impede monitoring or surveillance. }\end{array}$ \\
\end{tabular}

12. Many of these general guidelines could be easily met if a single dedicated space can be provided for the safeguards electronic equipment, plus additional data processing and transmission equipment that may become available in the future to simplify and expedite the safeguards activities. (Sect. 7.1)

13. Providing access to appropriate penetrations in Should be incorporated in guidelines as the containment building for data transfer lines serving the remote monitoring equipment/instrumentation (Sect. 7.1.1)

14. Providing support for an IAEA tamper resistant local area network connection at each safeguards measurement point (Sect. 7.1.1)

15. Making allowance for digitizing equipment at the measurement sites (Sect. 7.1.1)
IAEA equipment mounting areas should be provided with conduit/ cable runs that can be used for powering and networking equipment. Conduits and cable provided for use by IAEA equipment should be clearly marked to prevent inadvertent cutting or damage.

Mounting locations for IAEA measuring and surveillance instruments should include space for recording/digitizing devices near the instruments. The mounting space for recording devices should meet the applicable guidelines in this set for IAEA equipment mounting space.
General guideline directly applicable to NuScale.

General guideline directly applicable to NuScale.

16. Making a centralized site available for data recording, analysis and processing computers (Sect. 7.1.1) 


\begin{tabular}{|c|c|c|}
\hline \multicolumn{3}{|c|}{ NuScale Safeguards Functional Guidelines } \\
\hline IAEA TRS 392 Guidance & Discussion of Guideline & $\begin{array}{l}\text { NuScale Applicability / } \\
\text { Comments }\end{array}$ \\
\hline $\begin{array}{l}\text { 17. Giving consideration to } \\
\text { permitting transmission } \\
\text { facilities, e.g., a satellite } \\
\text { dish, at the plant site } \\
\text { (Sect. } 7.1 .1 \text { ) }\end{array}$ & $\begin{array}{l}\text { Infrastructure (e.g., conduit runs, hub } \\
\text { mounting spaces) should be provided to } \\
\text { permit networking of IAEA equipment to a } \\
\text { central hub in the IAEA Safeguards Room } \\
\text { with provisions for remote communication } \\
\text { with IAEA (e.g., Internet access or satellite } \\
\text { dish). }\end{array}$ & $\begin{array}{l}\text { General guideline directly } \\
\text { applicable to NuScale. }\end{array}$ \\
\hline $\begin{array}{l}\text { 18. Such accounting and } \\
\text { control may be facilitated } \\
\text { by a unique identifier for } \\
\text { each fuel assembly; this is } \\
\text { usually the fuel fabricator's } \\
\text { serial number placed on the } \\
\text { fuel assembly at the fuel } \\
\text { fabrication plant. The } \\
\text { identifier: } \\
\text { - Should be readable } \\
\text { from above when the } \\
\text { fuel is in the fresh fuel } \\
\text { storage area, the spent } \\
\text { fuel pool and, for } \\
\text { LWRs, the reactor } \\
\text { core during refueling; } \\
\text { Should ideally be } \\
\text { impossible to remove } \\
\text { or change and should } \\
\text { retain its legibility } \\
\text { throughout irradiation } \\
\text { and storage. In } \\
\text { practice, it is sufficient } \\
\text { if tampering is difficult } \\
\text { and is obvious upon } \\
\text { viewing by safeguards } \\
\text { inspectors. } \\
\text { (Sect. } 7.1 .2 \text { ) }\end{array}$ & $\begin{array}{l}\text { Fuel assemblies should be designed with } \\
\text { unique identifiers that are readable from } \\
\text { above when fuel is in the fresh fuel storage } \\
\text { area, the spent fuel pool and, for LWRs, the } \\
\text { reactor core during refueling. The fuel } \\
\text { assembly unique identifiers should be difficult } \\
\text { (or impossible) to remove or change, tamper } \\
\text { indicating, and remain legible throughout } \\
\text { irradiation and storage. }\end{array}$ & $\begin{array}{l}\text { Guideline is applicable to } \\
\text { NuScale but requires } \\
\text { modification to reflect the } \\
\text { differences between NuScale } \\
\text { refueling process and standard } \\
\text { LWR refueling process. }\end{array}$ \\
\hline $\begin{array}{l}\text { 19. Most modern off-load } \\
\text { refueled plants already use } \\
\text { and virtually all future, } \\
\text { advanced off-load refueled } \\
\text { plants are expected to use } \\
\text { reconstitutable fuel } \\
\text { assemblies (i.e., assemblies } \\
\text { which are designed for the } \\
\text { removal and replacement } \\
\text { of individual fuel rods), } \\
\text { and to practice }\end{array}$ & $\begin{array}{l}\text { Should be incorporated in guidelines as } \\
\text { infrastructure guideline. }\end{array}$ & \\
\hline
\end{tabular}




\begin{tabular}{|c|c|c|}
\hline IAEA TRS 392 Guidance & Discussion of Guideline & $\begin{array}{c}\text { NuScale Applicability / } \\
\text { Comments }\end{array}$ \\
\hline $\begin{array}{l}\text { reconstitution routinely } \\
\text { upon failure of individual } \\
\text { fuel rods prior to the } \\
\text { intended final cycle in the } \\
\text { reactor core of the fuel } \\
\text { assembly containing the } \\
\text { failed rod or rods. Further, } \\
\text { rod consolidation (i.e., the } \\
\text { disassembly of fuel } \\
\text { bundles into their } \\
\text { individual rods and the } \\
\text { other non-fuel hardware) } \\
\text { has been developed and } \\
\text { demonstrated and is an } \\
\text { option in some countries } \\
\text { for reducing the volume of } \\
\text { spent fuel waste. } \\
\text { Substantial reconstitution } \\
\text { or rod consolidation } \\
\text { operations make it } \\
\text { impractical to use fuel } \\
\text { assembly identifiers. (Sect. } \\
7.1 .2 \text { ) }\end{array}$ & & \\
\hline $\begin{array}{l}\text { 20. The installed safeguards } \\
\text { equipment needs to be } \\
\text { provided with a means to } \\
\text { ensure that any tampering } \\
\text { will be evident to IAEA } \\
\text { inspectors. (Sect. } 7.1 .3 \text { ) }\end{array}$ & $\begin{array}{l}\text { The installation of tamper indicating devices } \\
\text { on the IAEA equipment is an IAEA } \\
\text { responsibility. The design of safeguards } \\
\text { equipment should be such that tampering with } \\
\text { services (e.g., cabling/ conduit and power) } \\
\text { will be evident. No safeguards infrastructure } \\
\text { design guideline. }\end{array}$ & \\
\hline $\begin{array}{l}\text { 21. Sealing systems are an } \\
\text { effective and versatile } \\
\text { means of demonstrating } \\
\text { secure containment during } \\
\text { periods of inactivity. To be } \\
\text { effective the design must } \\
\text { provide: } \\
\text { - Barrier walls that are } \\
\text { secure, i.e., } \\
\text { continuous, have no } \\
\text { openings large enough } \\
\text { to permit the passage } \\
\text { of a fuel item and } \\
\text { cannot be easily } \\
\text { breached without } \\
\text { detection; }\end{array}$ & $\begin{array}{l}\text { All building structure access points within } \\
\text { reactor building and fuel storage areas that are } \\
\text { not routinely used should be designed with } \\
\text { fixtures that allow application of seals. } \\
\text { Fixtures for the application of seals should } \\
\text { provide protection of the wires and parts } \\
\text { comprising the seal from damage or } \\
\text { inadvertent breakage. The design of the } \\
\text { fixtures should be such that seals are in } \\
\text { accessible locations to permit convenient } \\
\text { application and removal of the seal and } \\
\text { inspector examination. } \\
\text { Barrier walls should be secure, i.e., } \\
\text { continuous, have no openings large enough to }\end{array}$ & $\begin{array}{l}\text { Guidelines are applicable to } \\
\text { NuScale but require } \\
\text { modification to reflect the } \\
\text { differences between NuScale } \\
\text { refueling process and standard } \\
\text { LWR refueling process. } \\
\text { The guideline for mounting } \\
\text { space for monitoring at } \\
\text { routinely used access points is } \\
\text { an aspect of the NuScale SDC. }\end{array}$ \\
\hline
\end{tabular}




\begin{tabular}{|c|c|c|}
\hline \multicolumn{3}{|c|}{ NuScale Safeguards Functional Guidelines } \\
\hline IAEA TRS 392 Guidance & Discussion of Guideline & $\begin{array}{c}\text { NuScale Applicability / } \\
\text { Comments }\end{array}$ \\
\hline $\begin{array}{l}\text { Accessibility of the } \\
\text { walls of the barrier for } \\
\text { inspection for } \\
\text { evidence of tampering; } \\
\text { Protection of the wires } \\
\text { and parts comprising } \\
\text { the seal from damage } \\
\text { or inadvertent } \\
\text { breakage; } \\
\text { Access to the } \\
\text { attachment point, i.e., } \\
\text { the holes, wire } \\
\text { threading path, etc., } \\
\text { that permit convenient } \\
\text { application and } \\
\text { removal of the seal. } \\
\text { (Sect. 7.1.3.1) }\end{array}$ & $\begin{array}{l}\text { permit the passage of a fuel item and cannot } \\
\text { be easily breached without detection and } \\
\text { should be accessible to provide for inspection } \\
\text { for evidence of tampering. }\end{array}$ & \\
\hline $\begin{array}{l}\text { 22. A design feature that would } \\
\text { facilitate seal operations is } \\
\text { the provision to store seal } \\
\text { interrogation equipment } \\
\text { (e.g., for ARC seals) } \\
\text { (Sect. 7.1.3.1) }\end{array}$ & $\begin{array}{l}\text { Should be incorporated in guidelines as } \\
\text { infrastructure guideline. }\end{array}$ & \\
\hline $\begin{array}{l}\text { 23. Safeguards surveillance } \\
\text { cameras can be installed to } \\
\text { view: } \\
\text { - The spent fuel pool, } \\
\text { - Reactor closure, } \\
\text { - Exit doors and hatches } \\
\text { through which spent } \\
\text { fuel could be removed. }\end{array}$ & $\begin{array}{l}\text { Should be incorporated in guidelines as } \\
\text { infrastructure guideline. }\end{array}$ & \\
\hline $\begin{array}{l}\text { Suitable locations need to } \\
\text { be identified by the IAEA } \\
\text { for the cameras such that: } \\
\text { - Their viewing angles } \\
\text { cover the area to be } \\
\text { watched, } \\
\text { - The view is clear and } \\
\text { unobstructed, } \\
\text { - The area viewed has } \\
\text { adequate } \\
\text { uninterruptible } \\
\text { illumination, } \\
\text { Interfering lighting } \\
\text { arrangements, e.g., }\end{array}$ & & \\
\hline
\end{tabular}




\begin{tabular}{lll}
\hline & NuScale Safeguards Functional Guidelines & NuScale Applicability / \\
Comments
\end{tabular}

25. Provision of appropriate backups for reasonably expected power supply or equipment failures (Sect. 7.1.3.2)

26. Provision of independent electrical circuits and switch gear to avoid the possibility of inadvertent interruptions of electric power to safeguards equipment (Sect. 7.1.3.2)
Provision of backup equipment or equipment design redundancy is an IAEA responsibility. Supporting infrastructure is a plant design guideline.
Mounting areas for IAEA recording/digitizing equipment (blue cabinets), IAEA data processing, network, transmission equipment (including the IAEA safeguards room) should be supplied with electrical power. Electrical power for IAEA equipment should be provided by dedicated circuits backed up by uninterruptible power systems and power conditioning to provide conditioned power under loss of normal power and line transient conditions. The required capabilities will be established based upon reliability and quality of the normal power supply. Circuits supplying IAEA equipment should be clearly marked at switchgear to prevent inadvertent de-energizing.

\section{Guidelines for Off-Load Fueled Reactors}

27. In the fresh fuel storage areas, the following design provisions may assist in the implementation of safeguards:
The design should permit fresh fuel receipt in a single identified area within which mounting space should be provided for monitoring/surveillance equipment. The fresh fuel storage area should be designed
General guideline directly applicable to NuScale.

The NuScale design is sufficiently similar to current light water reactor designs that these guidelines are applicable. 


\begin{tabular}{|c|c|c|}
\hline IAEA TRS 392 Guidance & Discussion of Guideline & $\begin{array}{c}\text { NuScale Applicability / } \\
\text { Comments }\end{array}$ \\
\hline $\begin{array}{l}\text { A minimum number of } \\
\text { openings in the } \\
\text { building structure } \\
\text { accessing the fresh } \\
\text { fuel storage area } \\
\text { (through which } \\
\text { removal of fuel could } \\
\text { take place), with } \\
\text { suitable arrangements, } \\
\text { if required by the } \\
\text { safeguards approach, } \\
\text { which allow sealing } \\
\text { and/or surveillance of } \\
\text { these openings; } \\
\text { Layout of the fresh } \\
\text { fuel storage area to } \\
\text { allow inspectors to } \\
\text { verify and } \\
\text { progressively seal } \\
\text { groups of fuel } \\
\text { assemblies as they are } \\
\text { put into storage } \\
\text { without affecting the } \\
\text { continuity of } \\
\text { knowledge of the } \\
\text { inventory already held; } \\
\text { Provision of adequate } \\
\text { space and illumination } \\
\text { between assemblies to } \\
\text { allow inspectors to } \\
\text { read the identifiers on } \\
\text { fuel assemblies and to } \\
\text { conduct NDA } \\
\text { (specifically provision } \\
\text { for the use of the } \\
\text { IAEA inspector's } \\
\text { portable NDA } \\
\text { equipment and } \\
\text { arrangement of fuel } \\
\text { within the storage area } \\
\text { to minimize the } \\
\text { necessity for moving } \\
\text { fuel to identify specific } \\
\text { assemblies.) (Sect. } \\
\text { 7.2.1) }\end{array}$ & $\begin{array}{l}\text { in a manner that permits it to be laid out so } \\
\text { that inspectors can verify and progressively } \\
\text { seal groups of fuel assemblies as they are put } \\
\text { into storage without affecting the continuity } \\
\text { of knowledge of the inventory already held. } \\
\text { The fresh fuel storage area should be } \\
\text { designed, with adequate illumination, in a } \\
\text { manner that permits it to be laid out and } \\
\text { storage arranged so that inspectors can read } \\
\text { the identifiers on fuel assemblies and can } \\
\text { conduct NDA with portable equipment, } \\
\text { minimizing the necessity for moving fuel to } \\
\text { identify specific assemblies. } \\
\text { Mounting space should be provided for } \\
\text { sufficient surveillance/monitoring equipment } \\
\text { to monitor/ record activities in all areas } \\
\text { through which fresh fuel passes from the } \\
\text { opening of sealed shipping containers to the } \\
\text { fresh fuel storage area. Mounting space } \\
\text { should also be provided for sufficient } \\
\text { surveillance/monitoring equipment to } \\
\text { monitor/ record movement from the fresh fuel } \\
\text { storage location to the spent fuel pool location } \\
\text { from which it is loaded into the reactor core. } \\
\text { These routes should be designed so that } \\
\text { unobstructed monitoring of fuel assemblies is } \\
\text { possible from receipt in sealed shipping } \\
\text { containers to loading into the reactor core. } \\
\text { The fresh fuel handling equipment should be } \\
\text { designed in a manner that permits monitoring } \\
\text { equipment located in a provided mounting } \\
\text { space to monitor its movement and operation. } \\
\text { See also guideline } 6 .\end{array}$ & \\
\hline 28. A suitable mounting for & Mounting space should be provided for & The more frequent refueling of \\
\hline
\end{tabular}




\section{NuScale Safeguards Functional Guidelines}

\section{IAEA TRS 392 Guidance}

surveillance equipment

which inspectors can use to

view the tops of the fuel

assemblies when the

reactor vessel is open

(Sect. 7.2.2).

29. An indexing mechanism on the refueling machine with a device which can identify the location of each assembly (Sect. 7.2.2) surveillance equipment which inspectors can

use to view the tops of the fuel assemblies

when the reactor vessel is open.
NuScale Applicability / Comments

modules in the NuScale design requires that this surveillance/ monitoring be possible when no inspectors are present.
30. Provisions for sealing the canal gate (when applicable) to prevent it being opened without the knowledge of the inspectors. (Sect. 7.2.2)
The canal gate should be designed with a fixture that allows the application of seals to prevent it being opened without the knowledge of the inspectors.
The refueling equipment should be designed with an indexing mechanism that can identify the location of each fuel assembly.
NuScale design differs and uses a single machine, the shuffler, to rearrange spent fuel and refuel the reactor cores. However, the guideline is still applicable.

The NuScale design is significantly different. Modules will be refueled between inspections. The key SDC concepts are verifying that modules are not diverted from normal refueling paths (using $\mathrm{C} / \mathrm{S}$ ), and that monitoring takes place whenever refueling is being done (using refueling pool gate monitor).

The NuScale design is significantly different. Modules will be refueled between inspections. The key SDC concept is verifying that modules have not been refueled out of sequence (using seals).

\section{accessible for inspection,}

easy to install and protected against damage.

The preferred core seals are usually indirect in that they are multi-point seals applied to the missile shield, the reactor slab or some other component, rather than directly to the reactor vessel. (Sect. 7.2.3)

32. Suitable arrangements for surveillance equipment to view reactor vessel operations whenever the vessel is open.
The reactor vessel and appurtenances should be designed in manner allows the application of seals to maintain continuity of knowledge of the nuclear material contained in the reactor core.
The NuScale design is significantly different. Modules will be refueled near the spent fuel storage area and there will be no fuel transfer 


\begin{tabular}{|c|c|c|}
\hline IAEA TRS 392 Guidance & Discussion of Guideline & $\begin{array}{c}\text { NuScale Applicability / } \\
\text { Comments }\end{array}$ \\
\hline (Sect. 7.2.3) & & $\begin{array}{l}\text { canal. The key SDC concept is } \\
\text { complete surveillance between } \\
\text { the spent fuel/ fresh fuel storage } \\
\text { area (spent fuel pool) and } \\
\text { reactor refueling area. Because } \\
\text { modules will be refueled } \\
\text { between inspections the } \\
\text { monitoring must be possible } \\
\text { without an inspector present. }\end{array}$ \\
\hline
\end{tabular}

33. Underwater illumination in the reactor vessel and sufficient water clarity to allow the inspector to count the fuel assemblies and read their identifiers.

(Sect. 7.2.3)

34. Suitable arrangements for the installation of surveillance equipment [in spent fuel storage area] (Sect. 7.2.4)

\section{Room light sources (in spent fuel storage area) preferably selected so that their spectrum does not overlap the characteristics of the ICVD imager (which is sensitive to the ultraviolet range); otherwise the signal/background advantage could be lost. (Sect. 7.2.4)}

36. Storage racks preferably configured in a single layer, which permits the viewing of the top of each fuel assembly and its identifier from directly above, e.g., there should not be any overhang over fuel storage locations.
Should be incorporated in guidelines as infrastructure guideline.
Mounting space(s) should be provided for sufficient radiation monitoring and surveillance equipment to monitor/record activities in the spent fuel storage area.
NuScale design differs and uses a single machine, the shuffler, to rearrange spent fuel and refuel the reactor cores. Thus, this guideline and guideline 28 are redundant.
Should be incorporated in guidelines as infrastructure guideline.

(Sect. 7.2.4)

\section{Provision for verifying and Should be incorporated in guidelines as}




\begin{tabular}{|c|c|c|}
\hline \multicolumn{3}{|c|}{ NuScale Safeguards Functional Guidelines } \\
\hline IAEA TRS 392 Guidance & Discussion of Guideline & $\begin{array}{l}\text { NuScale Applicability / } \\
\text { Comments }\end{array}$ \\
\hline $\begin{array}{l}\text { sealing the fuel in the } \\
\text { lower layer(s), if fuel is } \\
\text { stored in more than one } \\
\text { layer. (Sect. } 7.2 .4 \text { ) }\end{array}$ & infrastructure guideline. & \\
\hline $\begin{array}{l}\text { 38. An indexing system for the } \\
\text { identification of specific } \\
\text { fuel assembly locations } \\
\text { from the fuel handling } \\
\text { control point. (Sect. } 7.2 .4 \text { ) }\end{array}$ & $\begin{array}{l}\text { The spent fuel handling equipment should be } \\
\text { designed with an indexing mechanism that } \\
\text { can identify the location of each fuel } \\
\text { assembly. }\end{array}$ & $\begin{array}{l}\text { NuScale design differs and uses } \\
\text { a single machine, the shuffler, } \\
\text { to rearrange spent fuel and } \\
\text { refuel the reactor cores. } \\
\text { Therefore this guideline is } \\
\text { already addressed in guideline } \\
29 \text {. }\end{array}$ \\
\hline $\begin{array}{l}\text { 39. A minimum number of } \\
\text { openings in the building } \\
\text { structure through which it } \\
\text { is possible to transfer spent } \\
\text { fuel, with suitable } \\
\text { arrangements which allow } \\
\text { sealing and/or surveillance } \\
\text { of these openings. } \\
\text { (Sect. } 7.2 .4 \text { ) }\end{array}$ & $\begin{array}{l}\text { Should be incorporated in guidelines as } \\
\text { infrastructure guideline. }\end{array}$ & \\
\hline
\end{tabular}

40. Water clarity to allow easy visual inspection of the fuel Should be incorporated in guidelines as assemblies in their storage position and viewing of the Cerenkov glow from the assemblies. The latter requires water clarity in the ultraviolet as well as in the visible spectrum.

(Sect. 7.2.4)
41. Providing adequate working space on the bridge for inspectors and their equipment (Sect. 7.2.4)

42. For special cases (e.g., long cooled fuel or locations not vertically accessible) provision for raising assemblies to allow NDA by, for example, a Fork Detector (Sect. 7.2.4)

\section{infrastructure guideline.}

The spent fuel pool bridge(s) should be designed with adequate working space for inspectors and their equipment.
The NuScale design is sufficiently similar to a standard water cooled reactor that this guideline is applicable.
This is not a safeguards design guideline because it will be met by the design of the fuel handling equipment.

\section{Provisions in the facility}

The design should permit spent fuel loaded

Based upon the SDC, it appears 


\begin{tabular}{|c|c|c|}
\hline \multicolumn{3}{|c|}{ NuScale Safeguards Functional Guidelines } \\
\hline IAEA TRS 392 Guidance & Discussion of Guideline & $\begin{array}{c}\text { NuScale Applicability / } \\
\text { Comments }\end{array}$ \\
\hline $\begin{array}{l}\text { design, the fuel handling } \\
\text { process and the storage } \\
\text { configuration that facilitate } \\
\text { the verification of fuel } \\
\text { transfers out of the pool } \\
\text { (e.g., by a monitoring } \\
\text { system operating in an } \\
\text { unattended mode) (Sect. } \\
7.2 .4 \text { ) }\end{array}$ & $\begin{array}{l}\text { into shipping/storage casks only in, preferably } \\
\text { a single, designated cask loading area(s). } \\
\text { Mounting space should be provided for } \\
\text { sufficient surveillance/ monitoring equipment } \\
\text { to monitor/record activities in all areas } \\
\text { through which spent fuel assemblies pass } \\
\text { from the spent fuel storage pool to the sealing } \\
\text { of shipping/storage casks. The route of the } \\
\text { spent fuel from the pool to the cask should be } \\
\text { designed so that unobstructed surveillance/ } \\
\text { monitoring of spent fuel assemblies is } \\
\text { possible from removal from the spent fuel } \\
\text { storage racks to loading into the shipping/ } \\
\text { storage cask }\end{array}$ & $\begin{array}{l}\text { that these operations can be } \\
\text { limited to a single area for } \\
\text { NuScale. }\end{array}$ \\
\hline $\begin{array}{l}\text { 44. The location for } \\
\text { reconstitution should be } \\
\text { designed, if possible, such } \\
\text { that the flow of assemblies } \\
\text { and/or rods into and out of } \\
\text { the area follows predefined } \\
\text { routes which can be } \\
\text { monitored by IAEA } \\
\text { equipment. (Sect. } 7.2 .4 \text { ) }\end{array}$ & $\begin{array}{l}\text { The design should permit fuel reconstitution } \\
\text { activities only in, preferably a single, } \\
\text { designated fuel reconstitution area(s) using } \\
\text { only identified fuel reconstitution equipment. } \\
\text { Mounting space(s) should be provided for } \\
\text { sufficient radiation monitoring and } \\
\text { surveillance equipment to monitor/record } \\
\text { activities in the fuel reconstitution area. The } \\
\text { design and layout of the facility should be } \\
\text { such that continuous monitoring/surveillance, } \\
\text { from the mounting space(s) provided, can be } \\
\text { maintained for spent fuel assemblies in transit } \\
\text { between the spent fuel storage area and the } \\
\text { reconstitution area. The design and layout of } \\
\text { the facility should be such that continuous } \\
\text { surveillance/ monitoring from the mounting } \\
\text { space(s) provided, can be maintained for } \\
\text { radioactive waste generated in reconstitution } \\
\text { activities in transit between the reconstitution } \\
\text { area and loading into the radioactive waste } \\
\text { storage or shipping container }\end{array}$ & $\begin{array}{l}\text { Based upon the SDC, it appears } \\
\text { that these operations can be } \\
\text { limited to a single area for } \\
\text { NuScale. }\end{array}$ \\
\hline
\end{tabular}




\begin{tabular}{ccc}
\hline & NuScale Safeguards Functional Guidelines & \\
\hline IAEA TRS 392 Guidance & Discussion of Guideline & $\begin{array}{c}\text { NuScale Applicability / } \\
\text { Comments }\end{array}$ \\
\hline & Guidelines for On-Load Fueled Reactors &
\end{tabular}

\section{Guidelines for On-Load Fueled Reactors}

These guidelines of TRS 302 are not directly applicable to the LWR/PWR designs upon which the NuScale design is based. They are included to provide insights from on-line refuel designs that may be useful for the NuScale safeguards design concepts. However, no specific design guidelines were derived from them.

45. Layout of fuel transport routes to facilitate optical surveillance and/or radiation monitoring.

(Sect. 7.3)

46. Provision for the installation of optical surveillance capable of withstanding high radiation fields, e.g., radiationhardened CCTVs or shielded locations for standard cameras with overlapping fields of view to monitor the reactor end faces and transit routes to the new and spent fuel ports [of on-load refueled reactors]. As part of the CCTV option, provision should be made for the installation of yes/no radiation detectors, typically thermoluminescent dosimeters or PIN detectors, at new fuel ports. They should be shielded from the radiation emanating from other fuelling activities and mounted in tamper indicating enclosures. (Sect. 7.3.2)

47. The core refueling monitoring equipment must operate with high reliability. Access to the equipment for maintenance activities without the need for reactor shutdown should 


\begin{tabular}{|c|c|c|}
\hline IAEA TRS 392 Guidance & Discussion of Guideline & $\begin{array}{c}\text { NuScale Applicability / } \\
\text { Comments }\end{array}$ \\
\hline $\begin{array}{l}\text { be incorporated into the } \\
\text { design. For components } \\
\text { which remain difficult to } \\
\text { access, consideration } \\
\text { should be given to means } \\
\text { of maintenance and } \\
\text { possible replacement at } \\
\text { the end of their duty } \\
\text { cycle. (Sect. 7.3.2) }\end{array}$ & & \\
\hline
\end{tabular}

48. Provision for cabling for power and signals that must be passed through the vault shielding penetrations for surveillance equipment in ways that avoid damaging radiation fields and electromagnetic interference (Sect. 7.3.2)

49. Provision of space for tamper indicating cabinets for the associated electronics at a safe and convenient location outside the reactor vaults.

(Sect. 7.3.2)

50. The spent fuel transfer path [for on-load refueled reactors] should preferably be defined so that the spent fuel enters the storage area via spent fuel discharge ports. (Sect. 7.3.2)

51. A shielding penetration matching the collimator/guide tube design provided at the appropriate locations, along with an access route through the plant to permit the equipment to be installed (Sect. 7.3.2)

52. The available end of the guide tube should be accessible for IAEA 


\begin{tabular}{|c|c|c|}
\hline IAEA TRS 392 Guidance & Discussion of Guideline & $\begin{array}{c}\text { NuScale Applicability / } \\
\text { Comments }\end{array}$ \\
\hline \multicolumn{3}{|l|}{$\begin{array}{l}\text { inspection of covers and } \\
\text { seals. (Sect. 7.3.2) }\end{array}$} \\
\hline \multicolumn{3}{|l|}{$\begin{array}{l}\text { 53. Provision for the } \\
\text { installation of optical } \\
\text { surveillance equipment } \\
\text { such as CCTV cameras in } \\
\text { tamper-indicating } \\
\text { enclosures, with fields of } \\
\text { view unobstructed by } \\
\text { normal activities, } \\
\text { preferably overlapping for } \\
\text { redundancy [for spent fuel } \\
\text { storage areas of on load } \\
\text { refueled reactors } \\
\text { (Sect. 7.3.3.1) }\end{array}$} \\
\hline \multirow{2}{*}{\multicolumn{3}{|c|}{$\begin{array}{l}\text { 54. Provision for appropriate, } \\
\text { continuous illumination, } \\
\text { above and below the [spent } \\
\text { fuel] pool surface, } \\
\text { supplemented with portable } \\
\text { lighting (Sect. 7.3.3.1) }\end{array}$}} \\
\hline & & \\
\hline $\begin{array}{l}\text { 55. Well-defined flow path for } \\
\text { the spent fuel [to dry } \\
\text { storage casks] and the } \\
\text { provision of space for any } \\
\text { safeguards verification } \\
\text { equipment that might be } \\
\text { needed. (Sect. } 7.4 \text { ) }\end{array}$ & $\begin{array}{l}\text { Should be incorporated in guidelines as } \\
\text { infrastructure guideline. }\end{array}$ & $\begin{array}{l}\text { For NuScale, the loading of dry } \\
\text { storage casks is equivalent to } \\
\text { the loading of shipping cask for } \\
\text { off-site transport. }\end{array}$ \\
\hline
\end{tabular}






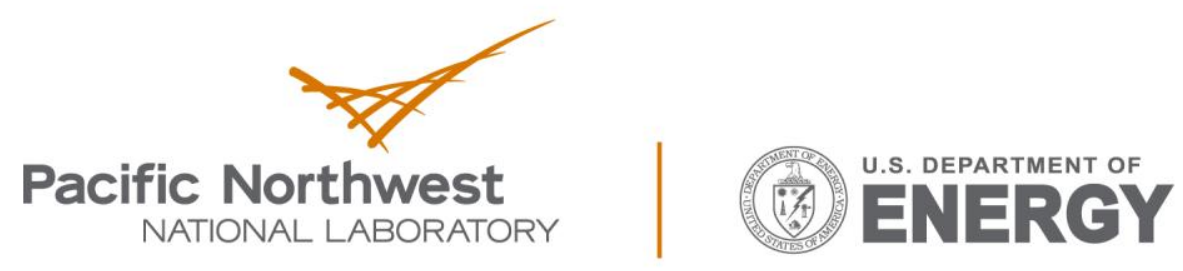

Proudly Operated by Battelle Since 1965

902 Battelle Boulevard

P.O. Box 999

Richland, WA 99352

1-888-375-PNNL (7665)

www.pnnl.gov 